\title{
Spore assemblages from Upper Ordovician and lowermost Silurian sediments recovered from the Qusaiba- 1 shallow core hole, Qasim region, central Saudi Arabia
}

\author{
Charles H. Wellman ${ }^{\text {a,* }}$, Philippe Steemans ${ }^{\mathrm{b}}$, Merrell A. Miller ${ }^{\mathrm{c}}$ \\ a Department of Animal and Plant Sciences, University of Sheffield, Alfred Denny Building, Western Bank, Sheffield S10 2TN, UK \\ b NFSR, Palaeobiogeology, Palaeobotany, Palaeopalynology, Liège University, Allée du 6 août, B-18, 4000 Liège, Belgium \\ c IRF Group, Inc., 2357 East 23rd street, Tulsa, OK 74114, USA
}

\section{A R T I C L E I N F O}

\section{Article history:}

Received 2 April 2014

Received in revised form 9 September 2014

Accepted 14 September 2014

Available online 13 October 2014

\section{Keywords:}

Qasim Formation (Quwarah Member)

Sarah Formation

Qalibah Formation (Qusaiba Member)

Early land plants

Cryptospores

Trilete spores

\begin{abstract}
A B S T R A C T
Palynological analysis of a sequence of Upper Ordovician to lowermost Silurian sediments from the Qusaiba-1 core hole drilled in the Qasim region of central Saudi Arabia has yielded rich palynomorph assemblages. The palynomorphs are abundant, exceptionally well preserved and of low thermal maturity. The sequence represents marine sediments that encompass glacial deposits representing the end Ordovician (Hirnantian) glaciation. All of the palynomorph assemblages are dominated by marine elements (acritarchs, chitinozoans, scolecodonts), although land-derived spores are present in most assemblages and are often moderately abundant. There is clear evidence for reworking into some of the glacial deposits. The strata are tightly age constrained based on chitinozoan and acritarch biostratigraphy, in addition to graptolite biostratigraphy in the lowermost Silurian deposits. In this paper we systematically describe the spores and erect two new taxa: a cryptospore permanent tetrad Tetraplanarisporites laevigatus gen. et sp. nov. and a trilete spore Chelinospora prisca sp. nov. We discuss the biostratigraphical implications of these tightly age constrained spore assemblages and recognise the need to establish regional rather than global spore biostratigraphic schemes in the Ordovician-early Silurian. We also discuss the palaeobotanical implications of the spore assemblages. The presence of true trilete and hilate spores, some of which are ornamented, suggests that a clade of plants characterised by trilete/hilate spore production may have evolved earlier in Gondwana than elsewhere. We develop evolutionary and palaeophytogeographical hypotheses to explain this early occurrence of trilete and hilate spores.
\end{abstract}

(c) 2014 Elsevier B.V. All rights reserved.

\section{Introduction}

A detailed palynological investigation has been undertaken on cored Upper Ordovician to lowermost Silurian strata penetrated by the Qusaiba-1 core hole (QSBA-1) from central Saudi Arabia (Fig. 1). All of the palynomorph groups encountered have been discussed and systematically described: acritarchs (Le Hérissé et al., 2008, 2014); chitinozoans (Paris et al., 2008a,2008b, 2014a,2014b); scolecodonts (Hints et al., 2008, 2014); and spores (Steemans et al., 2008, 2009; Wellman et al., 2008; this paper). These palynomorph groups have each been independently analysed to provide biostratigraphical age dating of the strata. Further evidence for the age of the sequence is provided by graptolites in the lowermost Silurian strata (Zalasiewicz et al., 2007) and the presence of Hirnantian glacial deposits. The combined palynological characteristics of the samples (palynofacies) have been integrated with sedimentological evidence (Melvin, 2014) to interpret

\footnotetext{
* Corresponding author.

E-mail address: c.wellman@sheffield.ac.uk (C.H. Wellman).
}

the geological setting and environments of deposition. The spore assemblages provide important evidence concerning the nature of Ordovician vegetation (its composition and palaeobiogeography). An important finding is the presence of true hilate spores and trilete spores in Ordovician deposits (Steemans et al., 2009). This is much earlier than previously reported and has important implications with respect to the nature of the early diversification of land plants. Hypotheses regarding the origin and palaeobiogeographical spread of hilate and trilete spore-producing plants are developed herein.

\section{Geological setting}

A substantial sequence of Ordovician deposits is present in Saudi Arabia (Figs. 2 and 3). The Qasim Formation consists of a thick sequence of Ordovician marine deposits of Mid to Late Ordovician age (Fig. 2). It conformably overlies the Saq Formation that is of CambrianEarly Ordovician (Tremadoc to Darriwilian (Tremadoc-Arenig)) age and is unconformably overlain by glacial deposits of the Sarah Formation that were deposited during the end Ordovician (Hirnantian) glaciation. The Qasim Formation is divided into four 


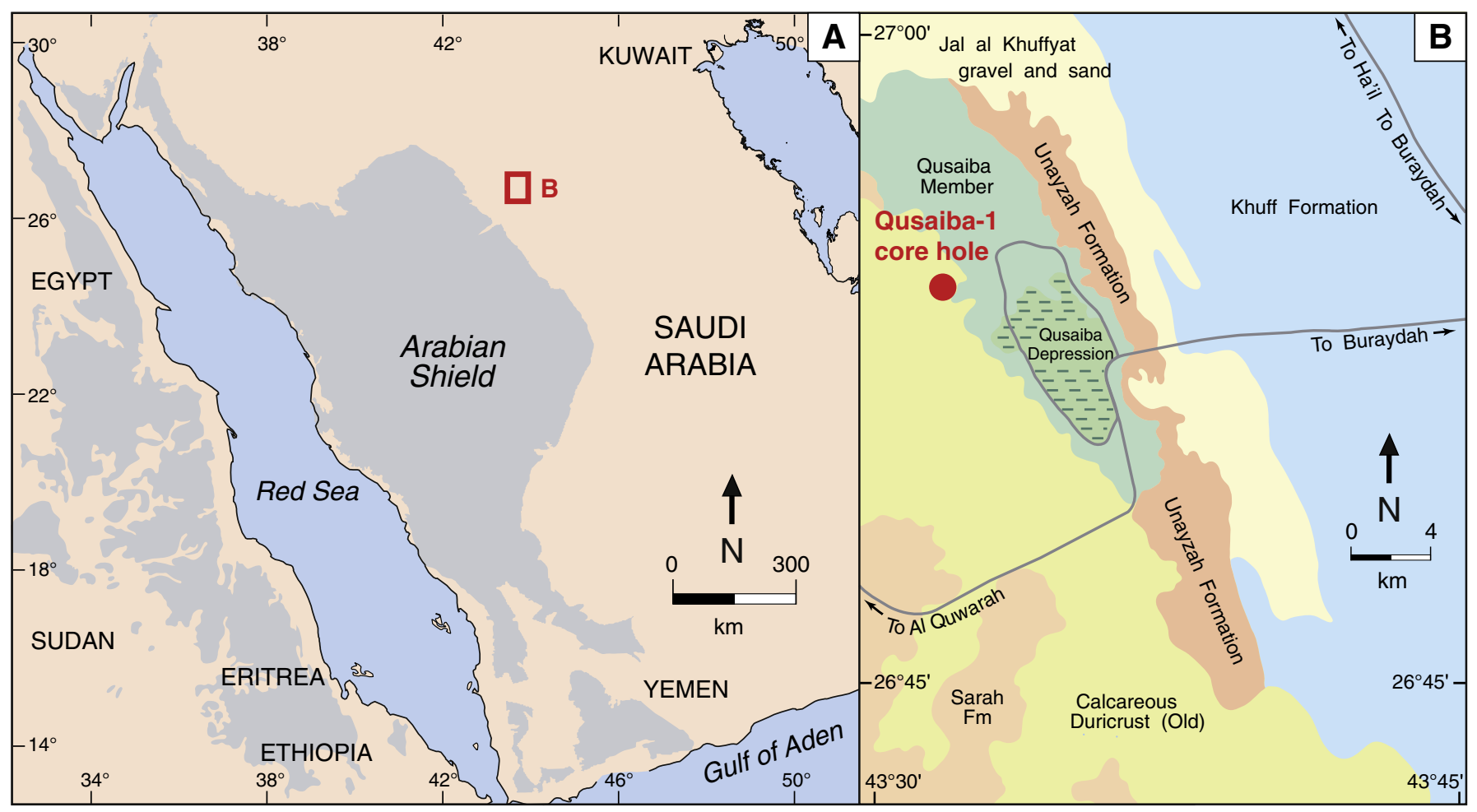

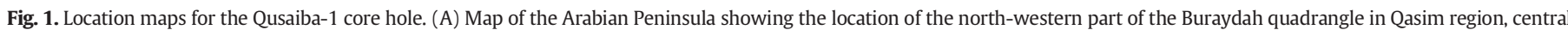

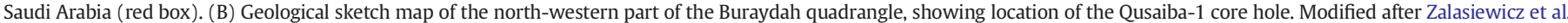
(2007).

members: the Hanadir, Kahfah, Ra'an and Quwarah members. The oldest Hanadir Member is of Darriwilian (late Arenig-early Llanvirn) age and consists of offshore shelf deposits. The overlying Kahfah Member is of late Darriwilian-early Sandbian (late Llanvirn-early Caradoc) age and consists of storm-dominated shallow marine deposits. This is overlain by the offshore shelf deposits of the Ra'an Member that are of late Sandbian-early Katian (Caradoc-?earliest Ashgill) age. The youngest member is the Quwarah Member that consists of tide-dominated shallow marine deposits of Katian (?latest Cardoc to early Ashgill) age. Details of the geology of the Ordovician sequence of Saudi Arabia, and in particular the Qasim Formation, are provided by Miller and Al-Ruwaili (2007).

The cored section of the Qusaiba-1 core hole penetrates the upper part of the Qasim Formation (Quwarah Member), the overlying Sarah Formation, and the lowermost part of the Qalibah Formation (Qusaiba Member). Melvin (2014) provides an in-depth review of the stratigraphy and sedimentology of the Ordovician-Silurian sequence penetrated by the Qusaiba-1 core hole. A detailed sedimentological log is provided in Fig. 3. The oldest samples examined are from the upper part of the Qasim Formation (Quwarah Member) and consist of a shallowing upward succession of offshore shelf interbedded sandstones, siltstones and mudstones (Melvin, 2014).

Two chitinozoan biozones are present in the Qasim Formation (Paris et al., 2008b, 2014b). The oldest samples are interpreted as not younger than early Katian (late Caradoc) in age, based on the chitinozoans present and the absence of important stratigraphic markers for the late Katian and Hirnantian. The succeeding chitinozoan assemblage indicates that the uppermost Qasim sediments are late Katian (early-mid Ashgill) in age. Acritarch biostratigraphy (Le Hérissé et al., 2008, 2014), consisting of diverse assemblages of acritarchs mainly of Katian age, is in agreement with that of chitinozoans.

The Qasim Formation is unconformably overlain by glacial advance and retreat facies of the Sarah Formation. This includes shallow- marine deposits (Baq'a Shale) in its upper part. The sediments of the Sarah Formation are characterised by Hirnantian acritarch species with reworked earlier Ordovician forms. The Qalibah Formation (Qusaiba Member) overlies the Sarah Formation and consists of shelfal marine deposits of Early Silurian age. Graptolites indicate these strata are not younger than Llandovery (mid Aeronian) in age (Zalasiewicz et al., 2007; Melvin, 2014). Evidence from chitinozoans suggests that there is possibly an early Rhuddanian condensed section (257$254.5 \mathrm{ft}$ ) followed by a mid-Aeronian interval (254.5-231 ft) (Paris et al., 2014b). The sedimentology, stratigraphy and palynology of the Qusaiba member has been discussed in detail by Miller and Melvin (2005).

\section{Material and methods}

Thirty-seven samples were collected from the cores in the Upper Ordovician strata penetrated by the lower part of the Qusaiba-1 core hole (Fig. 3; Table 2). They were prepared at the University of Liège, Belgium, using standard palynological $\mathrm{HCl}-\mathrm{HF}-\mathrm{HCl}$ acid maceration techniques. Each sample was crushed and around $30 \mathrm{~g}$ was demineralised in $\mathrm{HCl}-\mathrm{HF}$. The residue was briefly oxidized in $\mathrm{HNO}_{3}$ and $\mathrm{KClO}_{3}$ and sieved through a $12 \mu \mathrm{m}$ mesh. A hot bath in $25 \% \mathrm{HCl}$ eliminated the remaining fine mineral particles. All the samples were rinsed through a $12 \mu \mathrm{m}$ mesh. Subsequently selected duplicate samples were independently processed at the University of Sheffield and prepared using standard $\mathrm{HCl}-\mathrm{HF}-\mathrm{HCl}$ palynological acid maceration techniques, followed by heavy liquid (zinc bromide) separation and sieving using a $10 \mu \mathrm{m}$ mesh, and with no oxidation. The palynological characteristics of preparations from both laboratories were identical. All of the samples yielded rich organic residues including palynomorphs (miospores, acritarchs, chitinozoans) that are abundant, well-preserved and of low thermal maturity (spores are Thermal Alteration Index 1-2 based on the TAI scheme, and associated colour chart, in Traverse (2007)). Table 2 provides details of all the 


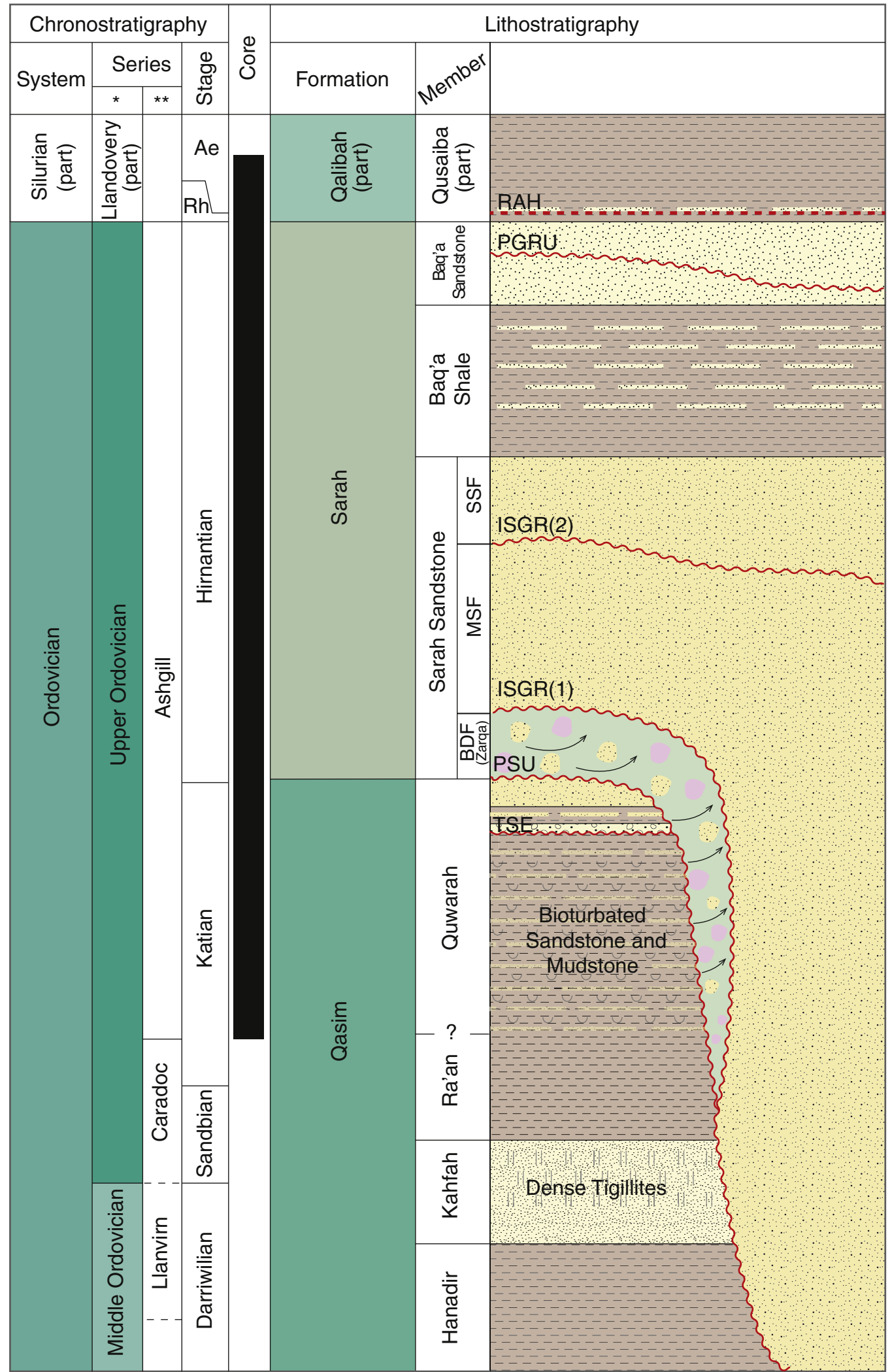

Fig. 2. Generalised stratigraphy (from Melvin (2014)).

samples processed. The samples were equally subdivided between PS/ $\mathrm{CHW}$ and logged. All the figured material is housed in the Centre for Palynology of the University of Sheffield. Individual specimens are located by providing slide details and England Finder Coordinates.

\section{Systematic part}

All of the spore taxa encountered are figured (Plates I-IV) (Table 1). Detailed descriptions are only provided for those new to science or 

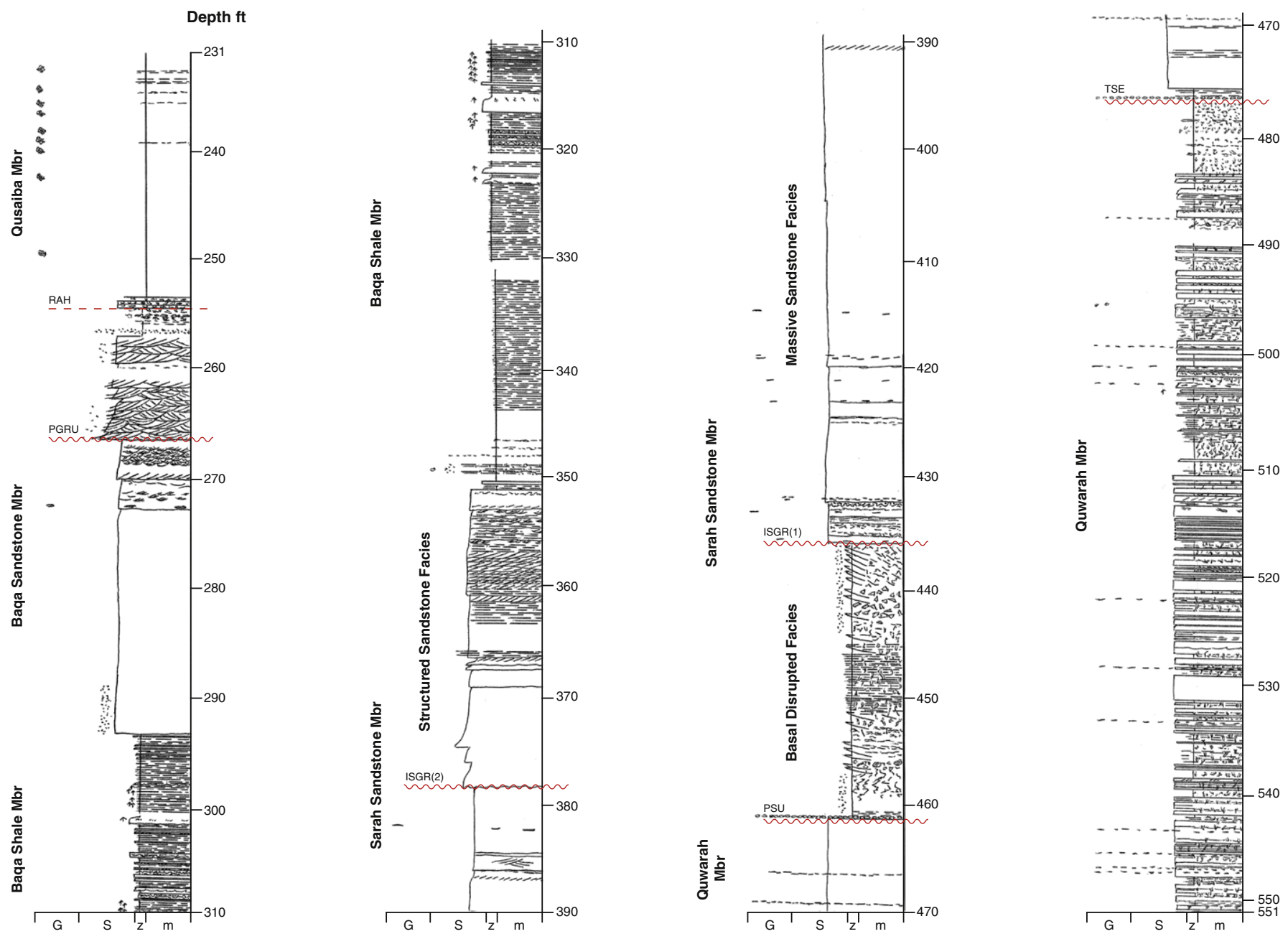

Fig. 3. Sedimentological log of the cored section of the Qusaiba-1 core hole (from Melvin (2014)).

those exhibiting features of particular interest. Spore taxa are grouped under general headings relating to gross structure and therein alphabetically.

\section{Cryptospores}

\section{Monads}

Genus Rugosphaera Strother and Traverse, 1979

Type species: Rugosphaera tuscarorensis Strother and Traverse, 1979

Rugosphaera? cerebra Miller and Eames, 1982 (Plate I, 1-2)

Remarks: These specimens appear to be naked, although we cannot rule out the possibility that they are enclosed within a tight-fitting laevigate envelope.

Dimensions: 31 and $35 \mu \mathrm{m}$ (2 specimens measured).

Rugosphaera sp. A (Plate I, 3-4)

Remarks: These specimens consist of a spore with a thick, laevigate wall that is enclosed within a loose-fitting envelope with an ornament of widely separated narrow muri.
Dimensions: 24 and $26 \mu \mathrm{m}$ (2 specimens measured).

\section{Dyads}

Genus Didymospora Strother et al., 2015-this volume

Type species: Didymospora luna Strother et al., 2015-this volume

Didymospora fucosogranulata Strother et al., 2015-this volume (Plate I, $8,11-12)$

Description: True dyad composed by two prominent but loosely attached spores. Exospore thick 3-5 $\mu \mathrm{m}$. Spores laevigate but with distinct infrastructure clearly visible within the thick walls. Rare specimens appear to have a tightly adherent, thin, laevigate envelope.

Dimensions: 29(38)40 $\mu \mathrm{m}$ in length (11 specimens measured).

Remarks: Similar tetrads occur in the assemblage described herein as Cryptotetras mordacis Strother et al., 2015-this volume

Tetrads

Genus Cryptotetras Strother et al., 2015-this volume

Type species: Cryptotetras erugata Strother et al., 2015-this volume 
Table 1

List of identified taxa.

\section{Cryptospore monads}

Rugosphaera? cerebra Miller and Eames, 1982 [Plate 1: 1-2] (31(33)35 $\mu \mathrm{m}-2$ specimens measured)

Rugosphaera sp. A [Plate 1: 3-4] (24(25)26 $\mu \mathrm{m}$ - 2 specimens measured)

Cryptospore dyads

Dyadospora murusattenuata Strother and Traverse, 1979, [Plate 1: 5] (25(31)39 $\mu \mathrm{m}$ - 14 specimens measured)

Dyadospora murusdensa Strother and Traverse, 1979 [Plate 1: 6-7] (27(36)49 $\mu \mathrm{m}$ - 15 specimens measured)

Didymospora fucosogranulata Strother et al., 2014 [Plate 1: 8, 11-12] (29(38)48 $\mu \mathrm{m}$ - 11 specimens measured)

Abditusdyadus chalazus? Wellman and Richardson, 1996 [Plate 1:9] (30(43)55 um - 2 specimens measured)

Abditusdyadus laevigatus? Wellman and Richardson, 1996 [Plate 1: 13-14] (27(36)46 $\mu \mathrm{m}$ - 9 specimens measured)

Pseudodyadospora laevigata Johnson, 1985 [Plate 1: 21-22] (26(32)40 $\mu \mathrm{m}$ - 11 specimens measured)

Pseudodyadospora petasus Wellman and Richardson, 1993 [Plate 1: 23-24] (23(28)34 $\mu \mathrm{m}$ - 9 specimens measured)

Segestrespora laevigata Burgess, 1991[Plate 1: 15-16] (33(37)43 $\mu \mathrm{m}-3$ specimens measured)

Segestrespora (Dyadospora) membranifera (Johnson) Burgess, 1991 [Plate 1: 17-18] (34(37)40 $\mu \mathrm{m}-3$ specimens measured)

Segestrespora (Pseudodyadospora) rugosa (Johnson) Burgess, 1991 [Plate1: 19-20] (29(38)44 $\mu \mathrm{m}$ - 7 specimens measured)

Segestrespora sp. with an envelope with an ornament of very course muri [Plate 1: 10] (41 $\mu \mathrm{m}-1$ specimen measured)

Cryptospore tetrads

Tetrahedraletes medinensis Strother and Traverse, 1979 [Plate 2: 1-2] (26(33)42 $\mu \mathrm{m}$ - 17 specimens measured)

Cryptotetrasmordacis Strother et al., 2015-this volume [Plate 2: 16-;17] (33(41)53 $\mu \mathrm{m}$ - 10 specimens measured)

Cheilotetras spp. Wellman and Richardson, 1993 [Plate 2: 3] (30(33)35 $\mu \mathrm{m}-2$ specimens measured)

Tetraplanarisporites laevigatus gen. and sp. nov. [Plate 2: 4-11] (32(40)50 $\mu \mathrm{m}$ - 24 specimens measured)

Tetraplanarisporites sp. A [Plate 2: 13-14] (50 and $54 \mu \mathrm{m}-2$ specimens measured)

Tetraplanarisporites sp. B [Plate 2: 15] (42 $\mu \mathrm{m}$ - 1 specimen measured)

Large unfused tetrad [Plate 2: 12] (62 $\mathrm{mm}-1$ specimen measured)

Velatitetras anatoliensis Steemans et al., 1996 [Plate 3: 1] (36 $\mu \mathrm{m}$ - 1 specimen measured)

Velatitetras laevigata Burgess, 1991 [Plate 3: 2-3] (23(34)39 $\mu \mathrm{m}$ - 9 specimens measured)

Velatitetras reticulata Burgess, 1991 [Plate 3: 4-5] (28(38)45 $\mu \mathrm{m}$ - 10 specimens measured)

Velatitetras rugulata Burgess, 1991 [Plate 3: 7-8] (30(39)48 $\mu \mathrm{m}$ - 11 specimens measured)

Velatitetras sp. with envelope with very fine reticulum [Plate 3: 6] (40 $\mu \mathrm{m}-1$ specimen measured)

Velatitetras sp. with envelope with very course reticulum [Plate 3: 9] (51 $\mu \mathrm{m}-1$ specimen measured)

Sphaerasaccus glabellus Steemans et al., 2000 [Plate 3: 10] (48 $\mu \mathrm{m}-1$ specimen measured)

Spores physically separated from cryptospore polyads

Imperfectotriletes patinatus Steemans et al., 2000 [Plate 3: 11-12] (25(29)35 $\mu \mathrm{m}-7$ specimens measured)

Imperfectotriletes (?Ambitisporites) varvdovae Steemans et al., 2000 [Plate 3: 16] (29 $\mu \mathrm{m}-1$ specimen measured)

cf. Laevolancis chibrikovae Steemans et al., 2000 [Plate 3: 13] (41 $\mu \mathrm{m}$ - 1 specimen measured)

Hilate spores

Laevolancis divellomedium (Chibrikova) Burgess and Richardson, 1991/Gneudnaspora (Laevolancis) divellomedia (Chibrikova) Balme, 1988 var. minor Breuer et al., 2007 [Plate 3: 14 15] (21(31)41 $\mu \mathrm{m}$ - 14 specimens measured)

Chelinohilates sp. A [Plate 3: 17-18] (35(37)39 $\mu \mathrm{m}-2$ specimens measured)

Chelinohilates sp. [Plate 3: 19] (35 $\mu \mathrm{m}-1$ specimen measured)

Trilete spores

Leiotriletes sp. A [Plate 4: 1] (24 $\mu \mathrm{m}-1$ specimen measured)

Ambitisporites avitus Hoffmeister, 1959 sensu Steemans et al., 1996 [Plate 4: 2-4] (31(37)44 $\mu \mathrm{m}$ - 3 specimens measured)

Aneurospora sp. A [Plate 4: 21-24] (30(34)38 $\mu \mathrm{m}-4$ specimens measured) (29(31)35 $\mu \mathrm{m}-22$ specimens measured)

Synorisporites? sp. A [Plate $4: 18$ ] (32 $\mu \mathrm{m}-1$ specimen measured)

Synorisporites sp. B [Plate 4: 19] (30 $\mu \mathrm{m}-1$ specimen measured)

Synorisporites? sp. C [Plate 4: 17] (30 $\mu \mathrm{m}-1$ specimen measured)

Chelinospora prisca sp. nov. [Plate 4: 5-16] (29(31)36 $\mu \mathrm{m}$ - 10 specimens measured)

Chelinospora sp. A [Plate 4: 20] (33 $\mu \mathrm{m}-1$ specimen measured)

Cryptotetras mordacis Strother et al., 2015-this volume (Plate II, 16-18)

Description: Tetrahedral tetrad composed by four prominent spores. Exospore thick 3-5 $\mu \mathrm{m}$. Spores laevigate but with distinct infrastructure clearly visible within the thick walls. Rare specimens appear to have a tightly adherent, thin, laevigate envelope.

Dimensions: 33(41)45 $\mu \mathrm{m}$ (10 specimens measured).

Remarks: Similar dyads occur in the assemblage described herein as Didymospora fucosogranulata Strother et al., 2015-this volume

\section{Genus Tetraplanarisporites gen. nov.}

Type species: Tetraplanarisporites laevigatus gen. and sp. nov.

Derivation of name: Refers to the planar organisation of the tetrad.

Diagnosis: Fused tetrad with a planar configuration. Tetrad laevigate. Naked or enclosed within a loose- or tight-fitting envelope. The envelope may be laevigate or variously ornamented. Lacking any haptotypic features.
Comparison: Tetraplanarisporites and Quadrisporites Hennelly, 1958 are both planar tetrads. However: (i) Quadrisporites often exhibits haptotypic features, (ii) some Quadrisporites are ornamented, (iii) Quadrisporites is never enclosed in an envelope, (iv) Quadrisporites may show a small free space in the centre of the tetrad. It is likely that Quadrisporites is a polyphyletic taxon (algal coenobia or cryptospores; see discussion in e.g., Strother (1991); Amenabar et al. (2006)). Tetraletes Cramer, 1966 is a junior synonym of Quadrisporites.

Remarks: Current systematic practice differentiates between cryptospores at the generic level depending on whether they are naked or enclosed within an envelope (Wellman, 1996; Wellman and Richardson, 1996). We have not followed this practice because the systematics concerning Quadrisporites is so confused that we have decided to clearly differentiate Tetraplanarisporites from all other planar tetrads. Naked and envelope-enclosed Tetraplanarisporites are essentially identical except for the envelope. Poorly preserved specimens which have lost their external envelope could not be differentiated from originally naked tetrads. The polyphyletic Quadrisporites group does not include tetrads enclosed in an envelope.

Tetraplanarisporites laevigatus gen. et sp. nov. (Plate II, 4-11) 
Table 2

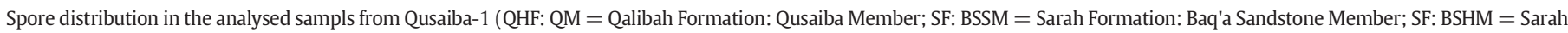

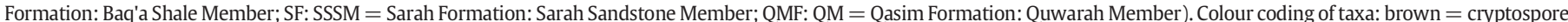
monads; blue = cryptospore dyads; pink = cryptospore tetrads; green $=$ spores physically dissociated from permanent monads; violet $=$ hilate spores; brown $=$ trilete spores.

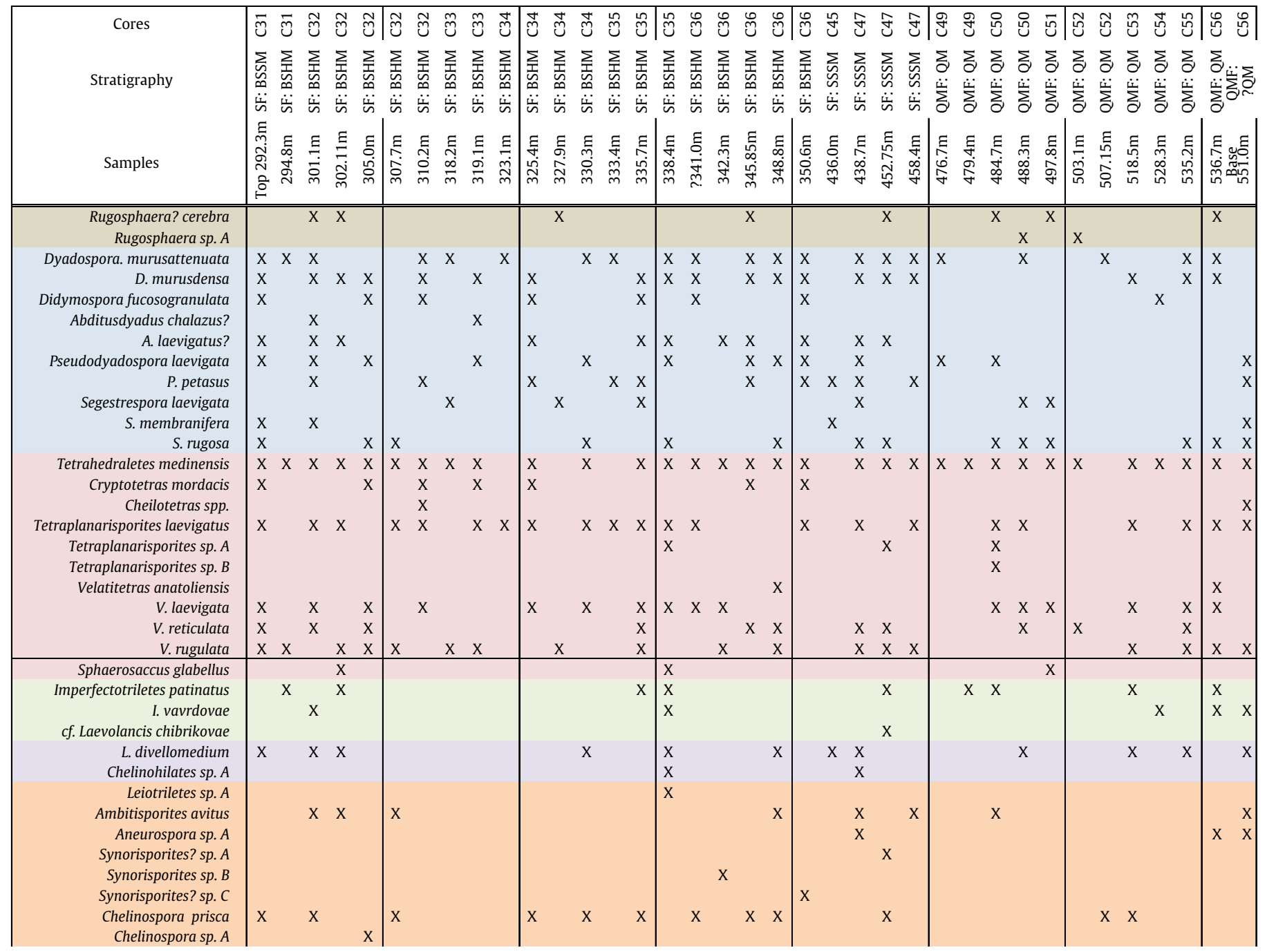

2006 Quadrisporites granulatus in Amenábar et al., figs. 4, E-F, I

Holotype: Pl. II, fig. 7, Qusaiba-1 borehole, Saudi Arabia, 488.3 ft., E.F.No. (R41/1/2).

Paratype: Pl. II, fig. 4, Qusaiba-1 borehole, Saudi Arabia, 518.5 ft., E.F.No. (K55/1).

Description: Planar tetrad with a cross-tetrad configuration giving it a characteristic '+-shape' or 'H-shape' when compressed. The exospore is laevigate and ca. $2 \mu \mathrm{m}$ in thickness.

Dimensions: 32(40)50 $\mu \mathrm{m}$ (24 specimens measured).

Comparison: Many specimens previously assigned to Quadrisporites granulatus may belong with T. laevigatus. One of the two specimens published by Cramer (1966) clearly shows cells with a split that probably corresponds to an aperture.

Remarks: The '+-shape' and 'H-shape' configurations differ because in the former all spores are in contact with all three other spores but in the latter two of the spores are in contact with all three other spores and two of the spores are in contact with only two of the other spores.
Tetraplanarisporites sp. A (Plate II, 13-14)

Description: Planar tetrad with a cross-tetrad configuration giving it a characteristic '+-shape' or 'H-shape' when compressed. The exospore is laevigate and ca. $2 \mu \mathrm{m}$ in thickness. Enclosed within a loose- or tight-fitting laevigate envelope.

Dimensions: 50 and $54 \mu \mathrm{m}$ (2 specimens measured).

Comparison: Tetraplanarisporites sp. A is identical to T. laevigatus except that it is enclosed within an envelope.

Tetraplanarisporites sp. B (Plate II, 15)

Description: Planar tetrad with a cross-tetrad configuration giving it a characteristic '+-shape' when compressed. The exospore is laevigate and ca. $2 \mu \mathrm{m}$ in thickness. Enclosed within a loose- or tight-fitting envelope.

The envelope is ornamented by low indistinct muri, $1 \mu \mathrm{m}$ in width, that form a pseudo reticulum with lumina $4-5 \mu \mathrm{m}$ in diameter.

Dimension: $42 \mu \mathrm{m}$ (1 specimen measured). 
Comparison: Tetraplanarisporites sp. B is identical to T. laevigatus except that it is enclosed within an envelope. T. sp. B differs from T. sp. A because the envelope is ornamented in the former and laevigate in the latter.

\section{Hilate spores}

Genus Chelinohilates Richardson, 1996b

Type species: Chelinohilates erraticus Richardson, 1996a

Chelinohilates sp. A (Plate III, 17-18)

Description: Amb circular. Proximal surface with a circular crassitude dividing a laevigate hilum from the remainder of the spore. Ornamented outside of the hilum with thin convolute muri forming an irregular reticulum. Muri $0.5-1.5 \mu \mathrm{m}$ tall and wide. Lumina of the reticulum 1-5 $\mu \mathrm{m}$ long 1-2 $\mu \mathrm{m}$ wide.

Dimensions: 35 and $39 \mu \mathrm{m}$.

Remarks: Only two specimens have been observed. The ornament of the distal reticulum distinguishes it from all other species of Chelinohilates.

\section{Trilete spores}

Genus Ambitisporites Hoffmeister, 1959

Type species: Ambitisporites avitus Hoffmeister, 1959.

Ambitisporites avitus Hoffmeister, 1959 sensu Steemans et al., 1996 (Plate IV, 2-4)

Remarks: Some of the specimens of Ambitisporites appear to exhibit a very faint 'ghostly' ornamentation on the distal face. This may represent indistinguishable low verrucae or muri.

Dimensions: 25, 28 and $31 \mu \mathrm{m}$ of diameter (3 specimens measured).

Comparisons: The faint ornament gives the spores a similar appearance to Aneurospora sp. A.

Genus Aneurospora Streel, 1964 emend. Richardson et al., 1982

Type species: Aneurospora goensis Streel, 1964.

Aneurospora sp. A (Plate IV, 21-24)

Description: Trilete spore with a subcircular shape and with a regular cingulum of $2 \mu \mathrm{m}$ width. The trilete mark is thin and reaches the cingulum. Proximal face laevigate and distal face ornamented by small indistinct grana densely packed.

Dimensions: $28 \mu \mathrm{m}$ (1 specimen measured).

Genus Chelinospora Allen, 1965 emend McGregor and Camfield, 1976

Type species: Chelinospora concinna Allen, 1965

Chelinospora prisca sp. nov. (Plate IV, 5-16)

?1991 Synorisporites cf. S.? libycus in Burgess and Richardson, p. 617618, Text-fig. 3I, J

Derivation of name: Refers to the very old age of this taxon of trilete spore; priscus: old (Latin).
Holotype and type locality: Plate IV, 5, Qusaiba-1 core hole, Saudi Arabia, 292.3 ft, E.F.no. (D42/3).

Paratype: Plate IV, 8, Qusaiba-1 borehole, Saudi Arabia, 325.4 ft., E.F.no. (Z43/2).

Description: Subtriangular to subcircular shape with a regular to irregular cingulum of 2.5 to $3 \mu \mathrm{m}$ width, the labra of the trilete mark is constant in width $(1.75 \mu \mathrm{m})$ on all its length. Proximal face laevigate. Distal face sculptured by dense low convolute muri of $1.5 \mu \mathrm{m}$ width.

Remarks: A possible continuous morphological transition between A. avitus and S. cf. S.? libycus could exist.

Dimensions: 29(31)36 $\mu \mathrm{m}$ (10 specimens measured)

Chelinospora sp. A (Plate IV, 20)

Description: Subtriangular shape with a thin cingulum, the trilete mark is straight and thin, the distal face is characterised by very thin convolute muri $(+/-1 \mu \mathrm{m}$ width) miming a pseudo-reticulum.

Dimension: $28 \mu \mathrm{m}$ (1 specimen measured)

Remark: This specimen is close to $C$. prisca but the labra of the trilete mark is thinner, the muri mimics a pseudo-reticulum.

Genus Leiotriletes Naumova ex Ishchenko, 1952

Type species: Leiotriletes sphaerotriangulatus Potonié and Kremp, 1954.

Leiotriletes sp. A (Plate IV, 1)

Description: This unique specimen has a subcircular shape and shows no thickening and a very thin trilete mark.

Dimensions: $21 \mu \mathrm{m}$ (1 specimen measured)

Genus Synorisporites Richardson and Lister, 1969

Type species: Synorisporites downtonensis Richardson and Lister, 1969.

Synorisporites? sp. A (Plate IV, 18)

Description: This unique specimen has a subtriangular shape with a regular equatorial thickening of $1.75 \mu \mathrm{m}$ width, a trilete mark very thin. The proximal face seems to be thinner than the distal one, which is ornamented by low rounded verrucae, larger at the distal pole where they are $2.5 \mu \mathrm{m}$ width and progressively less wide towards the equator where they are $1.75 \mu \mathrm{m}$.

Dimensions: $26 \mu \mathrm{m}$ (1 specimen measured)

Synorisporites sp. B (Plate IV, 19)

Description: Subtriangular shape, cingulum thin in the radial position (0.5-1 $\mu \mathrm{m}$ width). The labra of the trilete mark are thin, less than $1 \mu \mathrm{m}$ width. The distal face shows an indistinct ornamentation of grana and convolute short muri or folds of maximum $0.5 \mu \mathrm{m}$ width.

Dimension: $28 \mu \mathrm{m}$ (1 specimen measured)

Synorisporites? sp. C (Plate IV, 17)

Description: Subtriangular shape, with an equatorial cingulum of 2-3 $\mu \mathrm{m}$ width. The trilete mark is thick at the proximal pole and 
thinner towards the cingulum. An indistinct and irregular darker area surrounds the trilete mark. The distal face is characterised by ghostly verrucae.

Dimension: $30 \mu \mathrm{m}$ ( 1 specimen measured)

\section{Description of the spore assemblages}

The spore assemblages recovered from throughout the Qalibah Formation in the Qusaiba-1 core hole are essentially identical (see Table 2). Cryptospores are the most abundant spores. They consist predominantly

Plate I. All spores at magnification $\times 1000$. Sample number, well name and sample depth is followed by England Finder co-ordinate.

1. Rugosphaera? cerebra Miller and Eames, 1982; QSBA-1, $301.1 \mathrm{ft}, \mathrm{J} 44 / 4$.

2. Rugosphaera? cerebra Miller and Eames, 1982; QSBA-1, $345.85 \mathrm{ft}, \mathrm{H} 51 / 4$.

3. Rugosphaera sp. A; QSBA-1, $488.3 \mathrm{ft}, \mathrm{S} 50 / 3$.

4. Rugosphaera sp. A; QSBA-1, $503.1 \mathrm{ft}, \mathrm{L} 39 / 3$.

5. Dyadospora murusattenuata Strother and Traverse, 1979; OSBA-1, $438.7 \mathrm{ft}$, V51.

6. Dyadospora murusdensa Strother and Traverse, 1979; QSBA-1, $518.5 \mathrm{ft}, \mathrm{R} 33$.

7. Dyadospora murusdensa Strother and Traverse, 1979; QSBA-1, $325.4 \mathrm{ft}, \mathrm{T} 61 / 4$

8. Didymospora fucosogranulata Strother et al., 2014; QSBA-1, $310.5 \mathrm{ft}, \mathrm{E} 27 / 4$.

9. Abditusdyadus chalazus? Wellman and Richardson, 1996; QSBA-1, 301.1 ft, Q49/3-4.

10. Segestrespora sp. with an envelope with an ornament of course muri; QSBA-1, $438.7 \mathrm{ft}$, J34.

11. Didymospora fucosogranulata Strother et al., 2014; QSBA-1, $310.2 \mathrm{ft}, \mathrm{B} 31 / 1$.

12. Didymospora fucosogranulata Strother et al., 2014; QSBA-1, $310.2 \mathrm{ft}, \mathrm{P} 39 / 2$.

13. Abditusdyadus laevigatus? Wellman and Richardson, 1996; OSBA-1, $345.85 \mathrm{ft}, \mathrm{Q} 30$.

14. Abditusdyadus laevigatus? Wellman and Richardson, 1996; QSBA-1, $438.7 \mathrm{ft}, \mathrm{G} 39 / 2$.

15. Segestrespora laevigata Burgess, 1991; QSBA-1, $438.7 \mathrm{ft}, \mathrm{Z} 35$.

16. Segestrespora laevigata Burgess, 1991; QSBA-1, $488.3 \mathrm{ft}, \mathrm{D} 46 / 1$

17. Segestrespora membranifera (Johnson) Burgess, 1991; QSBA-1, $301.1 \mathrm{ft}, \mathrm{N} 31 / 3$.

18. Segestrespora membranifera (Johnson) Burgess, 1991; QSBA-1, $551 \mathrm{ft}, \mathrm{J} 45$.

19. Segestrespora rugosa (Johnson) Burgess, 1991; QSBA-1, $292.3 \mathrm{ft}, \mathrm{H} 44 / 4$.

20. Segestrespora rugosa (Johnson) Burgess, 1991; QSBA-1, $305 \mathrm{ft} ., \mathrm{C} 33 / 2$.

21. Pseudodyadospora laevigata Johnson, 1985; QSBA-1, $345.85 \mathrm{ft}, \mathrm{F} 36$.

22. Pseudodyadospora laevigata Johnson, 1985; QSBA-1, $350.6 \mathrm{ft}, \mathrm{U} 43$.

23. Pseudodyadospora petasus Wellman and Richardson, 1993; QSBA-1, $551 \mathrm{ft}, \mathrm{G} 34 / 2$.

24. Pseudodyadospora petasus Wellman and Richardson, 1993; QSBA-1, $458.4 \mathrm{ft}, \mathrm{L} 31 / 4$.

Plate II. All spores at magnification $\times 1000$. Sample number, well name and sample depth is followed by England Finder co-ordinate. (see on page 120 )

1. Tetrahedraletes medinensis Strother and Traverse, 1979; QSBA-1, $503.1 \mathrm{ft}, \mathrm{U} 55 / 1 / 2$.

2. Tetrahedraletes medinensis Strother and Traverse, 1979; QSBA-1, $518.5 \mathrm{ft}, \mathrm{E} 58 / 2$.

3. Cheilotetras spp.; QSBA-1, $310.2 \mathrm{ft}, 029 / 2$.

4. Tetraplanarisporites laevigatus gen. et sp. nov.; QSBA-1, $518.5 \mathrm{ft}, \mathrm{K} 55 / 1$.

5. Tetraplanarisporites laevigatus gen. et sp. nov.; QSBA-1, $458.4 \mathrm{ft}, \mathrm{F} 29 / 1$.

6. Tetraplanarisporites laevigatus gen. et sp. nov.; QSBA-1, $518.5 \mathrm{ft}, \mathrm{G} 58.4$.

7. Tetraplanarisporites laevigatus gen. et sp. nov.; Holotype; QSBA-1, $488.3 \mathrm{ft}, \mathrm{R} 43 / 1 / 2$.

8. Tetraplanarisporites laevigatus gen. et sp. nov.; QSBA-1, $555 \mathrm{ft}, \mathrm{K} 54$.

9. Tetraplanarisporites laevigatus gen. et sp. nov.; QSBA-1, $301.1 \mathrm{ft}, \mathrm{S} 29$.

10. Tetraplanarisporites laevigatus gen. et sp. nov.; Lateral compression; QSBA-1, $535.2 \mathrm{ft}, \mathrm{D} 51 / 4$.

11. Tetraplanarisporites laevigatus gen. et sp. nov.; QSBA-1, $458.4 \mathrm{ft}, \mathrm{G} 60$.

12. Large, naked, unfused tetrad; QSBA-1, $488.3 \mathrm{ft}, \mathrm{R} 31 / 3$.

13. Tetraplanarisporites sp. A; QSBA-1, $452.75 \mathrm{ft}, \mathrm{L} 31$.

14. Tetraplanarisporites sp. A; QSBA-1, $452.75 \mathrm{ft}, \mathrm{E} 46 / 3$.

15. Tetraplanarisporites sp. B; QSBA-1, $484.7 \mathrm{ft}, \mathrm{N} 44$.

16. Cryptotetras mordacis Strother et al., 2014; QSBA-1, $345.85 \mathrm{ft}, \mathrm{V} 29 / 2$.

17. Cryptotetras mordacis Strother et al., 2014; QSBA-1, $345.85 \mathrm{ft}, 043 / 1$.

18. Cryptotetras mordacis Strother et al., 2014; QSBA-1, $345.85 \mathrm{ft}, \mathrm{E} 41 / 2$.

Plate III. All spores at magnification $\times 1000$. Sample number, well name and sample depth is followed by England Finder co-ordinate. (see on page 121 )

1. Velatitetras anatoliensis Steemans et al., 1996; QSBA-1, $536.7 \mathrm{ft}, \mathrm{V} 33 / 4$.

2. Velatitetras laevigata Burgess, 1991; QSBA-1, $535.2 \mathrm{ft}, \mathrm{X} 50 / 2$.

3. Velatitetras laevigata Burgess, 1991; OSBA-1, $325.4 \mathrm{ft}, \mathrm{R} 33 / 3$.

4. Velatitetras reticulata Burgess, 1991; QSBA-1, $488.3 \mathrm{ft}$, L54.

5. Velatitetras reticulata Burgess, 1991; QSBA-1, $488.3 \mathrm{ft}, \mathrm{R} 41 / 1 / 2$.

6. Velatitetras sp. with envelope with very fine reticulum; QSBA-1, 301.1 ft, H58/4.

7. Velatitetras rugulata Burgess, 1991; QSBA-1, $518.5 \mathrm{ft}, \mathrm{L} 52$.

8. Velatitetras rugulata Burgess, 1991; QSBA-1, $535.2 \mathrm{ft}, \mathrm{B} 47$.

9. Velatitetras sp. with envelope with very coarse rugulae; QSBA-1, $325.4 \mathrm{ft}$, U36.

10. Sphaerasaccus glabellus Steemans et al., 2000; QSBA-1, $302.4 \mathrm{ft}, \mathrm{J} 33$.

11. Imperfectotriletes patinatus Steemans et al., 2000; QSBA-1, $518.5 \mathrm{ft}, \mathrm{R} 47 / 1$.

12. Imperfectotriletes patinatus Steemans et al., 2000; QSBA-1, $335.7 \mathrm{ft}, \mathrm{R} 27 / 4$.

13. cf. Laevolancis chibrikovae Steemans et al., 2000; QSBA-1, 535.2 ft, T28/2.

14. Laevolancis divellomedium (Chibrikova) Burgess and Richardson, 1991; QSBA-1, 535.2 ft, U51/2.

15. Laevolancis divellomedium (Chibrikova) Burgess and Richardson, 1991; QSBA-1, $551 \mathrm{ft}, \mathrm{E} 43.1$.

16. Imperfectotriletes vavrdovae (Richardson) Steemans et al., 2000; QSBA-1, $551 \mathrm{ft}, \mathrm{W} 55 / 4$.

17. Chelinohilates sp. A; QSBA-1, $342.3 \mathrm{ft}, \mathrm{M} 47 / 2$.

18. Chelinohilates sp. A; QSBA-1, $438.7 \mathrm{ft}, \mathrm{E} 59$.

19. Chelinohilates spp.; QSBA-1, $338.4 \mathrm{ft}$, L57/3. 

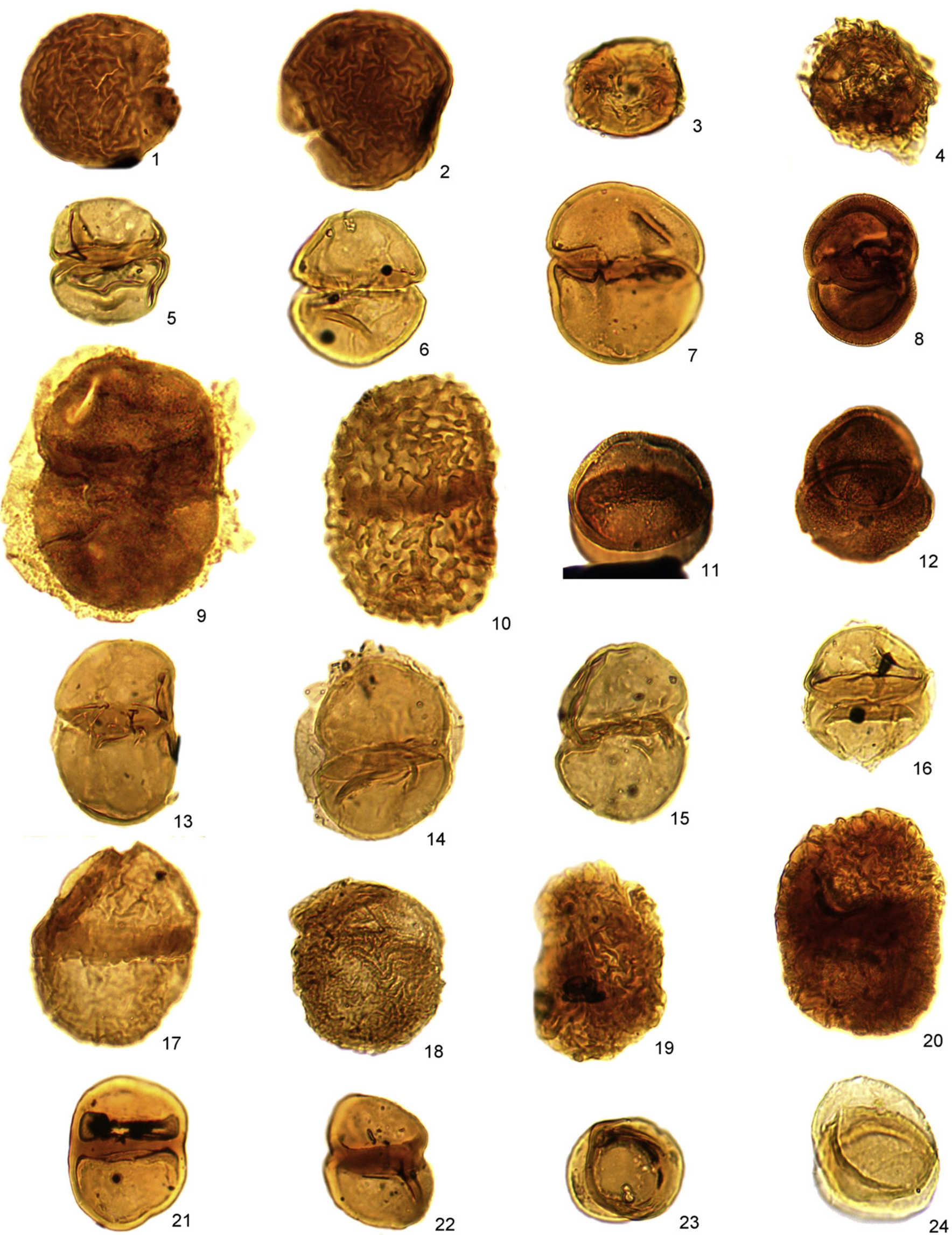

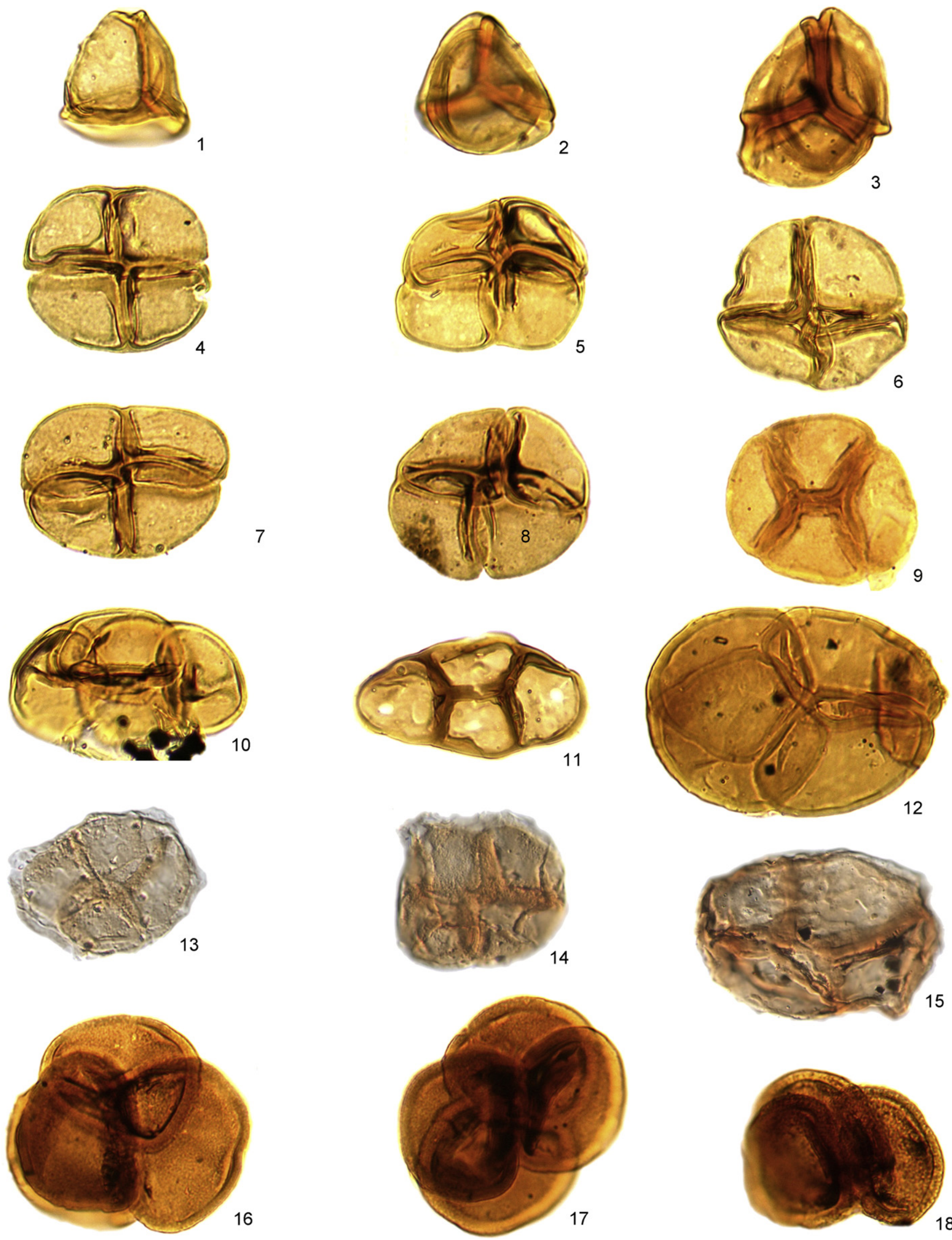

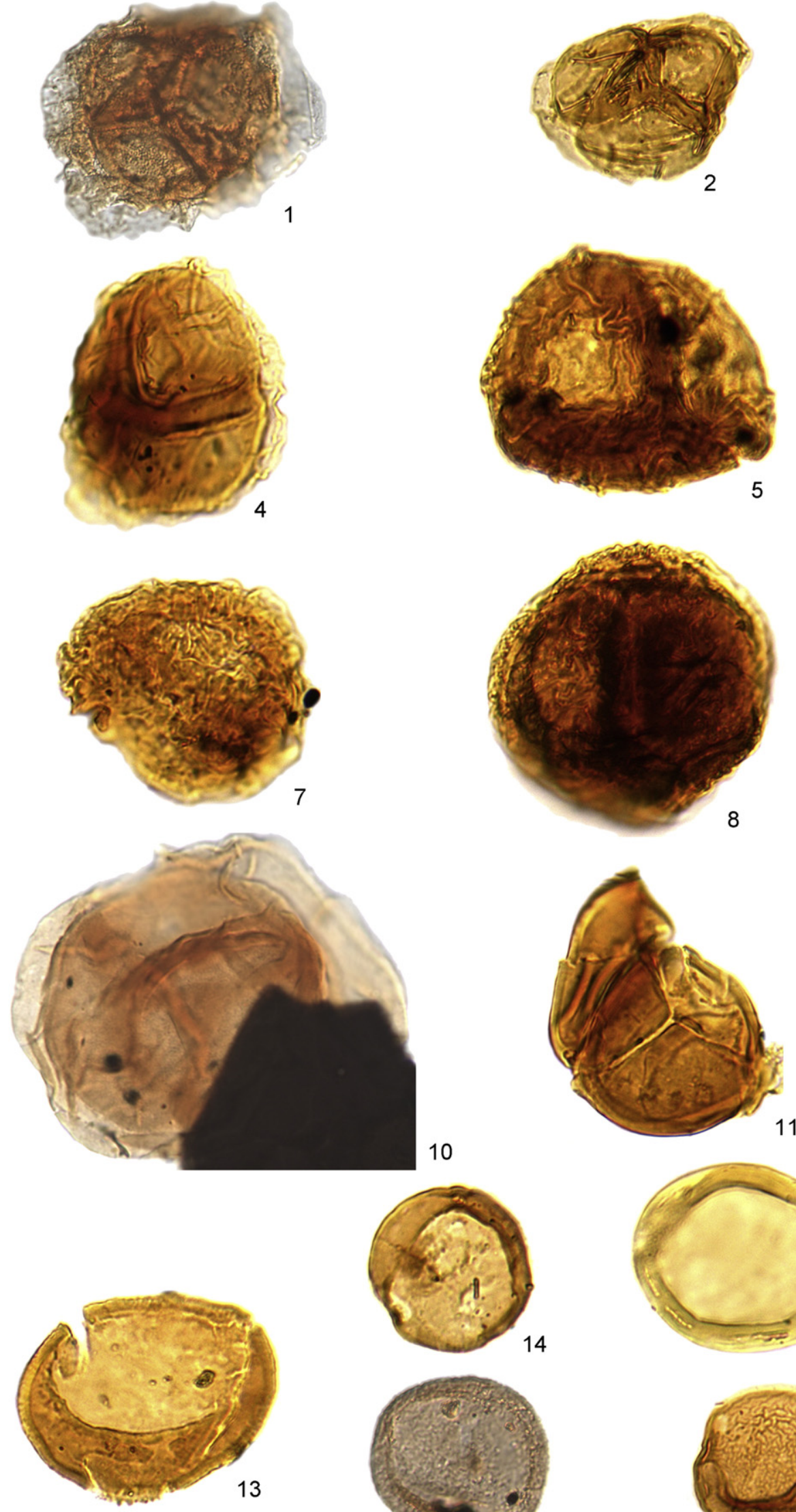

10
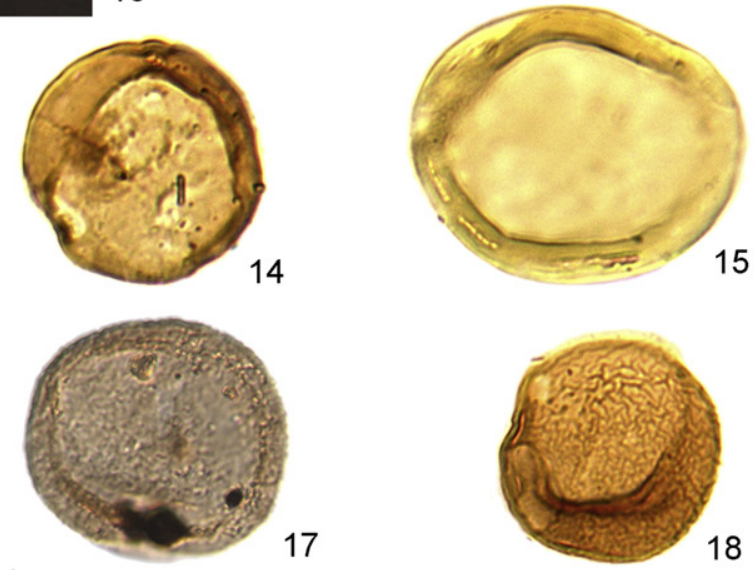
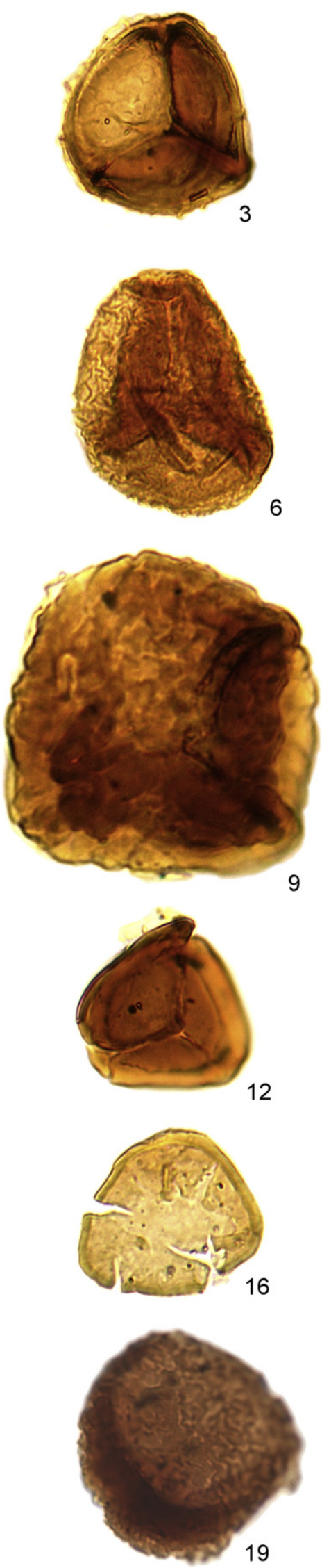
of monads, dyads and tetrads that are either naked or enclosed within variously ornamented envelopes. The dyads and tetrads include both fused and unfused forms. The cryptospores also include spores physically detached from polyad cryptospores. Naturally separating spores are present in the form of hilate spores (two taxa) and trilete spores (eight taxa) with both groups including laevigate and ornamented forms. These naturally separating spores are very rare compared to cryptospores (comprising less than $1 \%$ of the spore assemblage).

There are a number of interesting features of the spore assemblages. Firstly, a new genus and species of tetrad is described: Tetraplanarisporites. This taxon is unusual in that the tetrads occur in a planar tetrad configuration. The tetrads intergrade between an '+-shaped' and an 'H-shaped' configuration. Such spores have previously been reported only from Gondwana (Steemans et al., 2000; Strother et al., 1996; Wellman et al., 2000). This could be the oldest evidence of a Gondwanan endemism among plant producing cryptospores. Secondly, similar dyads and tetrads are present that are characterised by thick walls with infrastructure that imparts an apiculate appearance (see also Strother et al., 2015-this volume). Thirdly, the presence of naturally separating spores (hilate spores and trilete spores) is unprecedented in the Ordovician (Steemans et al., 2009) suggesting a very local endemism in this part of Gondwana.

\section{Biostratigraphical interpretation}

\subsection{Age dating}

All 37 samples yielded rich palynomorph assemblages comprising marine elements (abundant acritarchs and chitinozoans with rarer scolecodonts and graptolite fragments) and non-marine elements (land plant spores). Independent ages are provided by: (i) both chitinozoan (Paris et al., 2008a, 2008b, 2014a, 2014b) and acritarch (Le Hérissé et al., 2008, 2014) biostratigraphy; (ii) graptolite biostratigraphy in the upper units (Zalasiewicz et al., 2007); (iii) lithostratigraphical recognition of Hirnantian (end Ordovician) glacial deposits (e.g., Melvin, 2014).

The oldest section examined is from the upper part of the Qasim Formation (Quwarah Member), and consists of a shallowing upward succession of offshore shelf interbedded sandstones, siltstones and mudstones, from which the oldest samples were collected (Al-Hajri and Owens, 2000; Melvin, 2014). Two chitinozoan biozones are present in the Qasim Formation (Paris et al., 2008a, 2014a). The oldest samples are interpreted as not younger than mid-Katian (late Caradoc) in age, based on the chitinozoans present and the absence of important stratigraphic markers for the late Katian and Hirnantian. The succeeding chitinozoan assemblage indicates that the uppermost Qasim sediments are late Katian in age (early-mid Ashgill). Acritarch biostratigraphy, consisting of diverse assemblages of acritarchs mainly of Katian age from throughout the Qasim Formation, is in agreement with that of chitinozoans (Le Hérissé et al., 2008, 2014). The Qasim Formation is unconformably overlain by glacial advance and retreat facies of the Sarah Formation. To a certain extent this provides an independent lithostratigraphical age constraint in that these deposits are almost certainly produced by the Hirnantian (End Ordovician) glaciations. The Sarah Formation includes shallow marine deposits (Baq'a Shale) in its upper part (Senalp et al., 2002; Melvin, 2014). The sediments of the Sarah Formation are characterised by Hirnantian acritarch species with reworked earlier Ordovician assemblages (Le Hérissé et al., 2008, 2014). The Qalibah Formation (Qusaiba Member) overlies the Sarah Formation and consists of shelfal marine deposits of Early Silurian age based on graptolite and palynological evidence (Al-Hajri and Owens, 2000; Zalasiewicz et al., 2007; Paris et al., 2008b, 2014b).

\subsection{Miospore biozonation schemes}

Attempts to create miospore biozones around the Ordovician-Silurian boundary have been proposed by Richardson (1988) on the basis of material from the UK and Libya and by Steemans et al. (2000) on the basis of material from Saudi Arabia. Both schemes are limited because they are based on only a few samples from a palaeogeographically restricted area and were erected when cryptospore studies were still in their infancy. The results outlined in this paper conflict with both biozonations. They demonstrate that undoubted true hilate spores and trilete spores (including ornamented forms) occur below the Hirnantian. cf. Laevolancis chibrikovae Steemans et al., 2000 has previously been reported from the Ordovician but is not considered to be a true hilate cryptospore. Rather it is a monad formed by physical dissociation of a permanent dyad. Indeed remains of the other spore of the dyad are sometimes still attached to the physically separated monads. Hitherto the earliest report of trilete spores were very rare laevigate trilete spores (Ambitisporites avitus-dilutus Morphon Steemans et al., 1996) reported from the Hirnantian of Turkey (Steemans et al., 1996).

We consider that at this stage of our knowledge there is little value in attempting to place the Qusaiba-1 spore assemblage within the previously proposed miospore biozonation schemes of Richardson (1988) and Steemans et al. (2000). As an increasing amount of information becomes available on Ordovician miospore distribution it is becoming

\footnotetext{
1. Leiotriletes sp. A; QSBA-1, $338.4 \mathrm{ft}, \mathrm{L} 50$.

2. Ambitisporites avitus Hoffmeister (1959) sensu Steemans et al., 1996; QSBA-1, $301.1 \mathrm{ft}, \mathrm{B} 31$

3. Ambitisporites avitus Hoffmeister (1959) sensu Steemans et al., 1996; QSBA-1, $301.1 \mathrm{ft}, \mathrm{M} 42$.

4. Ambitisporites avitus Hoffmeister (1959) sensu Steemans et al., 1996; QSBA-1, $458.4 \mathrm{ft}, \mathrm{K} 40 / 4$.

5. Chelinospora prisca sp. nov.; Holotype; QSBA-1, $292.3 \mathrm{ft}, \mathrm{D} 42 / 3$.

6. Chelinospora prisca sp. nov.; QSBA-1, $301.1 \mathrm{ft}, \mathrm{E} 43 / 4$.

7. Chelinospora prisca sp. nov.; QSBA-1, $325.4 \mathrm{ft}, \mathrm{H} 34 / 3$.

8. Chelinospora prisca sp. nov.; OSBA-1, $325.4 \mathrm{ft}, \mathrm{Z} 43 / 2$.

9. Chelinospora prisca sp. nov.; QSBA-1, $330.3 \mathrm{ft}$, U38/4.

10. Chelinospora prisca sp. nov.; QSBA-1, $335.7 \mathrm{ft}, \mathrm{M} 55 / 4$.

11. Chelinospora prisca sp. nov.; QSBA-1, $335.7 \mathrm{ft}, \mathrm{P} 51 / 4$.

12. Chelinospora prisca sp. nov.; QSBA-1, $341 \mathrm{ft}, \mathrm{B} 40 / 4$.

13. Chelinospora prisca sp. nov.; QSBA-1, $341 \mathrm{ft}, \mathrm{N} 47 / 3$.

14. Chelinospora prisca sp. nov.; QSBA-1, $345.85 \mathrm{ft}, \mathrm{U} 44 / 1$

15. Chelinospora prisca sp. nov.; QSBA-1, $438.7 \mathrm{ft}$, Y54.

16. Chelinospora prisca sp. nov.; QSBA-1, $518.5 \mathrm{ft}, \mathrm{P} 30 / 3$.

17. Synorisporites? sp. C; QSBA-1, $350.6 \mathrm{ft}, \mathrm{Z} 40 / 2$.

18. Synorisporites? sp. A; QSBA-1, $452.75 \mathrm{ft}, \mathrm{G} 28$.

19. Synorisporites sp. B; QSBA-1, $342.3 \mathrm{ft}, \mathrm{K} 44$.

20. Chelinospora sp. A; QSBA-1, $305 \mathrm{ft}, \mathrm{W} 27 / 3$.

21. Aneurospora sp. A; QSBA-1, $452.75 \mathrm{ft}, \mathrm{S} 45 / 3$.

22. Aneurospora sp. A; QSBA-1, $438.7 \mathrm{ft}, \mathrm{D} 50 / 4$

23. Aneurospora sp. A; QSBA-1, 64163, $551 \mathrm{ft}, \mathrm{X} 42 / 3$.

24. Aneurospora sp. A; QSBA-1, $438.7 \mathrm{ft}, \mathrm{G} 51$.
}

Plate IV. All spores at magnification $\times 1000$. Sample number, well name and sample depth is followed by England Finder co-ordinate. 

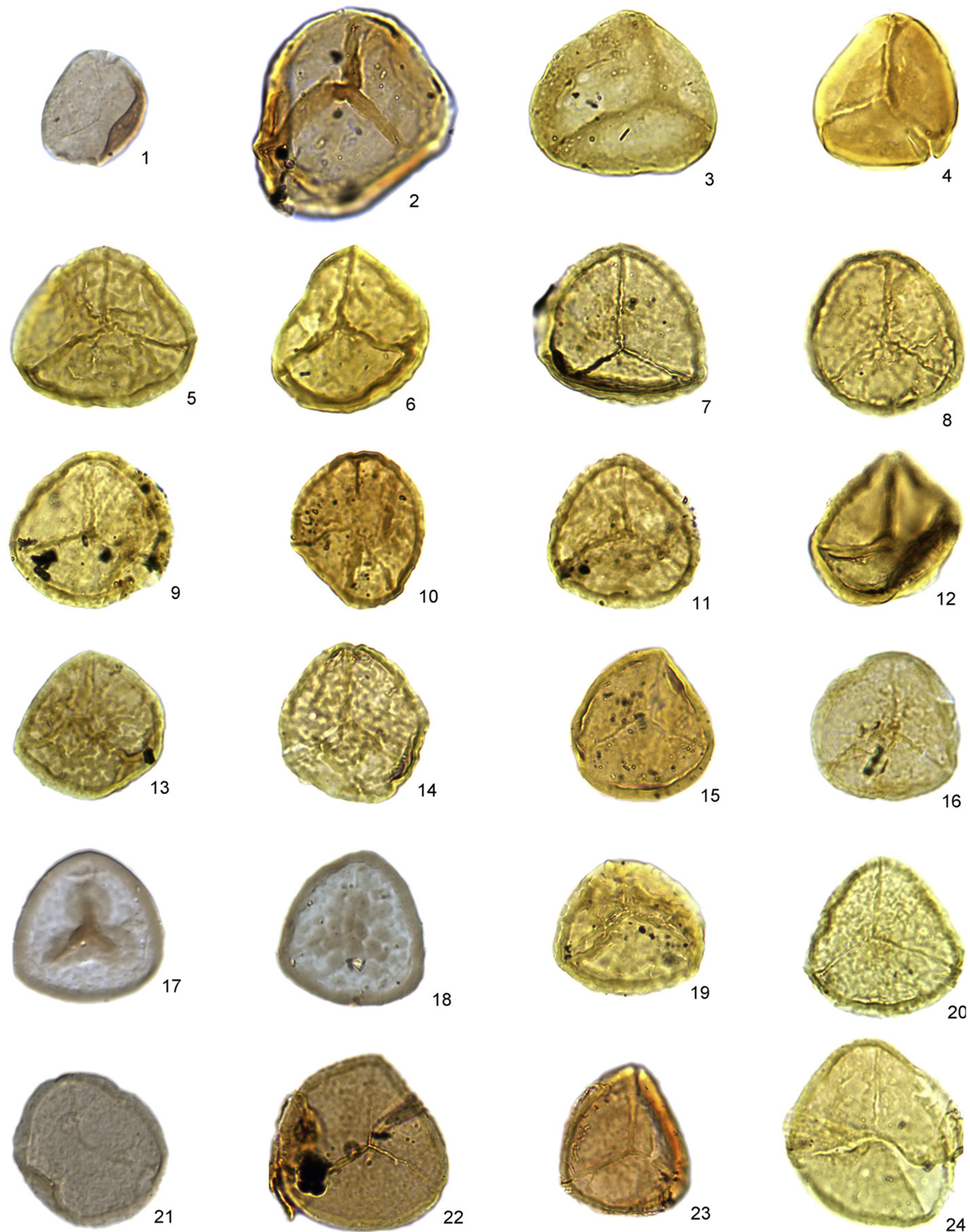
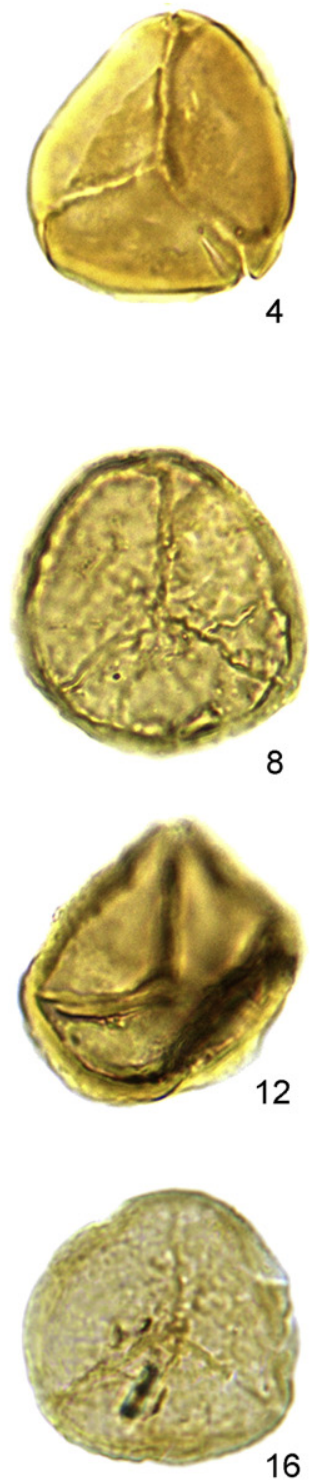

6
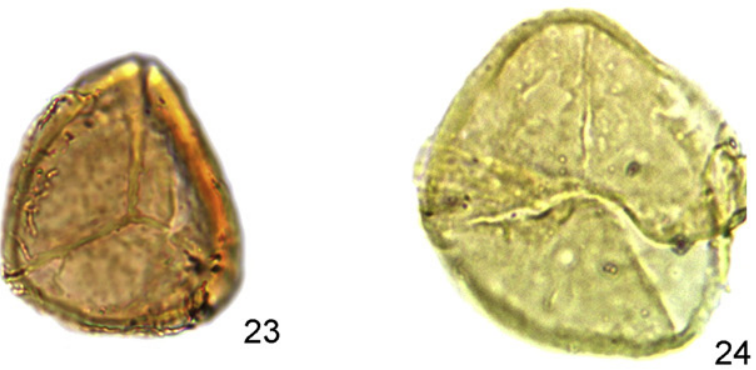
apparent that both their spatial and temporal distribution is complex. It appears that there is significant palaeogeographical variation with complex patterns of origination, dispersal (immigration and emigration), and extinction. Consequently the development of a global miospore biozonation scheme in the Ordovician seems an unlikely goal. A more sensible option may be to develop local and regional schemes and attempt to correlate these with one another.

\section{Palaeogeographical and palaeoenvironmental interpretation}

During the Mid-Late Ordovician Saudi Arabia was located on the western margin of the continent Gondwana and situated at midlatitudes (between 30 and $60^{\circ}$ south of the equator) (Cocks and Torsvik, 2002). The climate has been interpreted as warm and cool temperate (Boucot in Scotese, 2013), but most likely with a distinct cooling associated with the onset of the Hirnantian glaciation. The deposits of the Qusaiba-1 core hole are interpreted as accumulating in the shallow seas on the continental shelf of Gondwana, in a variety of environments, water depths and distances from shore (see Melvin, 2014). Palynofacies of the Qusaiba-1 Ordovician deposits support these palaeoenvironmental interpretatione. The deposits appear to be entirely marine. All of the palynological preparations are dominated by marine palynomorphs (acritarchs, chitinozoans, scolecodonts). Spores account for rather low abundances of the palynomorphs, indicating true marine environments some distance from shore. In general it appears that the sediments become increasingly proximal to the shoreline up sequence (Melvin, 2014). Presumably the spores were produced by vegetation on the Gondwanan mainland and transported into the nearshore shallow marine deposits by wind and water.

\section{Palaeobotanical implications}

The discovery of true hilate spores and trilete spores in the Ordovician deposits of Saudi Arabia has important palaeobotanical implications as reported on and discussed in Steemans et al. (2009). In this section we expand upon those discussions.

The invasion of the land by plants (embryophytes) is considered to have occurred in a stepwise fashion from at least the Mid-Ordovician (Gray, 1985; Richardson, 1996a; Steemans, 2000; Wellman and Gray, 2000; Kenrick et al., 2012). The earliest vegetation of stem group embryophytes probably consisted of diminutive plants with bryophytelike anatomy and physiology (Gray, 1985). This flora of ecological generalists appears to have been cosmopolitan and dominated the planet, relatively unchanged, for some 50 million years (Gray, 1985; Richardson, 1996a; Steemans, 2000; Wellman and Gray, 2000; Rubinstein et al., 2010; Kenrick et al., 2012). It is represented in the fossil record by dispersed spores that are arranged in unusual configurations (cryptospores) and fragmentary remains of their parent plants (Wellman et al., 2003). A dramatic change in the dispersed spore record is documented in the early Silurian when cryptospore abundance and diversity diminishes as trilete spores appeared, became abundant and diversified through the late Silurian (Gray, 1985; Richardson, 1996a; Steemans, 2000; Wellman and Gray, 2000; Kenrick et al., 2012). This change is interpreted as reflecting the origin and adaptive radiation of vascular plants and their precursors (stem group vascular plants: protracheophytes) (Gray, 1985; Wellman and Gray, 2000). Our findings of hilate spores/trilete spores from the Late Ordovician of Gondwana is the earliest record of such spores to date and is remarkable in the diversity of the spores (in terms of structure and ornament). It suggests that the origin and diversification of vascular plants may have been neither sudden nor rapid. Rather it occurred earlier on Gondwana at southern high latitudes, before vascular plants dispersed to populate other continents where they secondarily diversified (see also Steemans et al. (2010)).

Cryptospores are the most abundant non-marine palynomorphs recovered from the Late Ordovician sediments of the Qusaiba-1 core hole.
They are similar to forms in other coeval assemblages found worldwide, with numerous monads, dyads and tetrads that are either naked or envelope-enclosed. Surprisingly, all of the samples also contain spores naturally dissociated from polyads: hilate spores from dyads and trilete spores from tetrads. The two species of hilate spore include an unornamented and an ornamented form. Eight trilete spore taxa are identified. Two are unornamented and the other six variously ornamented with verrucae and muri. Neither hilate spores nor trilete spores have previously been reported from strata of this age. The oldest previous report of unornamented hilate spores is from the Early Silurian (Llandovery) (Richardson, 1996a; Steemans, 2000; Wellman and Gray, 2000; Wellman et al., 2000). Unornamented trilete spores were also believed to first appear in the Llandovery (Gray, 1985; Burgess, 1991; Richardson, 1996a; Steemans, 2000; Strother, 2000; Wellman and Gray, 2000), although rare specimens have been recorded in Hirnantian deposits from Turkey (northern Gondwana) (Steemans et al., 1996). Ornamented hilate and trilete spores have not previously been reported from strata older than Middle Silurian (Wenlock) (Gray, 1985; Burgess and Richardson, 1991; Richardson, 1996a; Steemans, 2000; Strother, 2000; Wellman and Gray, 2000). Thus the hilate and trilete spores from Saudi Arabia exhibit a surprising degree of morphologic diversity. This discovery in the Ordovician suggests that our understanding of the earliest vegetation and its terrestrialization must be re-evaluated.

Land plants (embryophytes) are a monophyletic group that evolved as an adaptive response to the invasion of land (e.g., Kenrick and Crane, 1997). They are believed to have evolved from a charophycean green algal ancestor (Graham, 1993). Extant basal land plant relationships are poorly resolved and fiercely contested (Kenrick and Crane, 1997; Crane et al., 2004; Qiu et al., 2006). Recent studies based on molecular and/or morphological data suggest that liverworts are the earliest divergent extant plant group and either mosses, or more likely hornworts, form a sister group relationship with vascular plants (e.g., Qiu et al., 2006). The most reliable source of information concerning the invasion of the land by plants is their fossil records: (i) body fossils of the actual plants (the megafossil record); (ii) dispersed spores/pollen propagules released in abundance by plants (the microfossil record) (e.g., Gray, 1985; Richardson, 1996a; Steemans, 2000; Strother, 2000; Wellman and Gray, 2000; Edwards and Wellman, 2001; Kenrick et al., 2012).

The earliest land plants are believed to have been stem group embryophytes that were diminutive and possessed bryophyte-like anatomy and physiology (Gray, 1985; Wellman and Gray, 2000). Unfortunately they left little in the way of a megafossil record; presumably because they lacked preservable tissues as do extant bryophytes. Fortunately, they are represented by a rich dispersed spore record (e.g., Gray, 1985; Richardson, 1996a; Steemans, 2000; Strother, 2000; Wellman and Gray, 2000). These dispersed spores are arranged in unusual configurations and are termed cryptospores. They show many characteristics similar to the spores of extant bryophytes (Gray, 1985; Taylor, 2001), and have been reported from mesofossil sporangia of Late Ordovician age (Wellman et al., 2003). Cryptospores have been reported from throughout the globe from high to low latitudes, including glacial deposits that accumulated during the Hirnantian glaciations (Gray, 1985; Richardson, 1996a; Steemans, 2000; Strother, 2000; Wellman and Gray, 2000), suggesting that the earliest vegetation was palaeogeographically widespread and generalist in terms of climatic requirements. The cryptospore record also exhibits stasis with very little spatial or temporal variation for at least 50 million years (Gray, 1985; Richardson, 1996a; Wellman, 1996; Steemans, 2000; Wellman and Gray, 2000; Rubinstein et al., 2010), although stasis evident in the spores may have masked important changes in the parent plants that are not preserved.

Until now it was generally accepted that this 50 million year period of vegetation stasis ended in the early Silurian (e.g., Gray, 1985; Richardson, 1996a; Steemans, 2000; Wellman and Gray, 2000; Wellman et al., 2000; Kenrick et al., 2012). At this time dispersed spore assemblages underwent a dramatic change with the appearance 
of hilate and trilete spores and their subsequent diversification in the Late Silurian (e.g., Burgess and Richardson, 1991; Beck and Strother, 2008). Various cryptospore groups became extinct (e.g., many envelope-enclosed forms) and others were relegated to subsidiary importance in dispersed spore assemblages. This major change, welldocumented in Laurentia (Beck and Strother, 2008) and Avalonia (e.g., Burgess, 1991; Burgess and Richardson, 1991), is usually equated with the radiation (and possibly origin) of vascular plants (Gray, 1985; Wellman and Gray, 2000). It was considered to have been rapid and globally contemporaneous. Recently, the reality of this adaptive radiation has been questioned following the report of trilete spores from the Hirnantian of Turkey (Steemans et al., 1996) and now, much more demonstrably, the discovery of even earlier trilete spores from Saudi Arabia discussed herein.

The appearance and adaptive radiation of hilate/trilete spores are usually considered to reflect the emergence of vascular plants. Gray (1985) argued persuasively that trilete spores derived predominantly from vascular plants. Extant basal vascular plants groups ('pteridophytes' or non-seed plants), essentially the lycopsids and ferns, nearly all produce dissociated single spores that are in either the trilete or the more derived monolete form. Similarly, a survey of the vast record of fossil 'pteridophytes' demonstrates they nearly all produce trilete or monolete spores (Balme, 1995). This includes various stem group tracheophytes (protracheophytes) such as Aglaophyton (Wellman et al., 2006). Furthermore, Gray demonstrated that trilete spores are rare among the extant 'bryophyte' groups (Gray, 1985). They are produced by most hornworts, some mosses (Sphagnales and some Andreaeales, Pottiales, Funariales and Isobryales) and rarely among the liverworts (some Marchantiales). In many of these cases the spores are termed cryptotrilete because the trilete mark is merely a scar formed during ontogeny by contact with the other members of the tetrad and is not a functional germination suture (Gray, 1985). Gray (1985) estimated that only some $2.5 \%$ of extant 'bryophyte' genera produce trilete spores, and many of these are cryptotrilete forms. True trilete marks are characterised by a suture and often associated lips, which are usually discernible in fossil trilete spores, including many of those in the present study.

It seems likely that the ancestral condition among embryophytes was to disperse meiotically produced spores united permanently in either tetrads or dyads. Dissociation of these units into individual trilete spores (from tetrads) or hilate spores (from dyads) is a more derived condition. This was probably adopted by either the polysporangiates (protracheophytes plus tracheophytes) or a clade consisting of the hornworts + polysporangiates. Either way it is clear that in a small number of cases, such as the Sphagnales, trilete spores appear to have subsequently evolved independently due to convergence. Extant bryophyte groups probably began to diverge from the stem group embryophytes at the same time as vascular land plants were undergoing an adaptive radiation (Late Silurian-Devonian). Certainly key characters of extant bryophytes were acquired by at least the Mid-Devonian (Hernick et al., 2008; Guo et al., 2012). It would appear that during this time many of the extant bryophyte groups also changed reproductive strategy with many plants adopting early tetrad disaggregation and dispersal of individual spores. Some extant forms retain the ancestral permanent tetrad condition (e.g., Sphaerocarpales) (Gray, 1985). Many, such as most extant mosses, adopted very early tetrad dissociation (prior to spore wall formation) that results in individual inaperturate spores. Delay in tetrad dissociation may also result in cryptotrilete spores with non-functional trilete marks.

Further evidence that the appearance and diversification of hilate/ trilete spores reflects vascular plants comes from the megafossil record. The earliest plants belonging to the vascular plant lineage, simple rhyniophytes of the Cooksonia-type, are reported from the late Wenlock of Avalonia (Edwards and Feehan, 1980). These are more-or-less coincident with the appearance and diversification of hilate/trilete spores in this area (Burgess, 1991; Burgess and Richardson, 1991). Better preserved Cooksonia from the late Silurian (Pridoli) are demonstrably vascular plants with simple conducting tissues (Edwards et al., 1992). These plants are exceptionally preserved by charcoalification (Glasspool et al., 2004) and retain exquisite anatomical detail including in situ spores (Fanning et al., 1988). It is clear that these and other polysporangiate plants produced trilete spores (Fanning et al., 1988), but occasionally hilate spores (Wellman et al., 1998a,1998b). In situ trilete spores from different Cooksonia species are either unornamented, have a simple murornate ornament, or a more complex apiculate ornament. The in situ spores are similar to those reported herein from the Ordovician of Saudi Arabia. There appears to be a progression of morphological variation from laevigate to murornate to apiculate that is observable in the dispersed spore record (in the Late Ordovician of northern Gondwana and the Late Silurian of Laurentia and Avalonia) and in situ spores preserved in plant megafossils from the latter.

It seems apparent that once they evolved vascular plants outcompeted the cosmopolitan vegetation of stem group embryophytes. Presumably vascular plants could grow larger and explore whole new vistas of morphospace due to a combination of: (i) switching the dominant phase in the lifecycle from the haploid to diploid generation; (ii) producing lignified tracheids that not only provided a more effective internal water transport system but also provided better support. As vascular plants diversified through the Late Silurian-Early Devonian they appear to have outcompeted the diminutive, bryophyte-like, stem group embryophytes. Clearly not all of these plants became extinct. Many would have persisted, but only in inhospitable environments unoccupied by the vascular plants, as evidenced by the persistence of small quantities of cryptospores in the dispersed spore record (e.g., Wellman and Richardson, 1996). It seems likely that the extant 'bryophyte' groups evolved from within this complex and persisted through to the present day, albeit as a subsidiary element of the biota confined to marginal habitats unexploited by the vascular plants.

Thus it remains clear that the invasion of the land by plants occurred in a stepwise pattern. However, the adaptive radiation of vascular plants and their precursors was neither as rapid nor explosive as it has previously been considered (Gray, 1985; Wellman and Gray, 2000). It seems more likely that they evolved early and persisted in small numbers for some time before palaeogeographically spreading and undergoing an adaptive radiation (probably evolving in southern high latitudes before migrating towards the equator and into the northern hemisphere) (see Steemans et al., 2010). This may be analogous to the "slow fuse" sometimes claimed for the Cambrian Explosion of multicellular animals (e.g., Conway Morris, 2000).

\section{Acknowledgements}

We would like to thank Saudi Aramco for making this material available for study and our colleagues in the CIMP Saudi Aramco project for freely sharing information on the various aspects of the Qusaiba-1 core hole studied during the course of this project.

\section{References}

Al-Hajri, S., Owens, B., 2000. Sub-surface palynostratigraphy of the Palaeozoic of Saudi Arabia. In: Al-Hajri, S., Owens, B. (Eds.), Stratigraphic PAlynology of the Palaeozoic of Saudi Arabia. GeoArabia Special Publication 1, pp. 10-17.

Allen, K.C., 1965. Lower and Middle Devonian spores of North and Central Vestspitsbergen. Palaeontology 8, 687-748.

Amenabar, C.R., Di Pasquo, M., Carrizo, H.A., Azcuy, C.L., 2006. Palynology of the Chigua (Devonian) and Maliman (Carboniferous) formations in the Volcan Range, San Juan Province, Argentina. Part 1. Paleomicroplankton and acavate smooth and ornamented spores. Ameghiniana 43, 339-375.

Balme, B.E., 1988. Spores from Late Devonian (early Frasnian) strata, Carnarvon Basin. Western Australia. Palaeontographica Abt. B 209, 109-166.

Balme, B.E., 1995. Fossil in situ spores and pollen grains: an annotated catalogue. Rev. Palaeobot. Palynol. 87, 81-323.

Beck, J.H., Strother, P.K., 2008. Miospores and cryptospores from the Silurian section at Allenport, Pennsylvania, USA. J. Paleontol. 82, 857-883.

Breuer, P., Al-Ghazi, A., Al-Ruwali, M., Higgs, K.T., Steemans, P., Wellman, C.H., 2007. Early to Middle Devonian miospores from northern Saudi Arabia. Rev. Micropaleontol. 50, 27-57. 
Burgess, N.D., 1991. Silurian cryptospores and miospores from the type Llandovery area, south-west Wales. Palaeontology 34, 575-599.

Burgess, N.D., Richardson, J.B., 1991. Silurian cryptospores and miospores from the type Wenlock area, Shropshire, England. Palaeontology 34, 601-628.

Cocks, L.R.M., Torsvik, T.H., 2002. Earth geography from 500 to 400 million years ago: a faunal and palaeomagnetic review. J. Geol. Soc. 159, 631-644.

Conway Morris, S., 2000. The Cambrian "explosion": Slow-fuse or megatonnage? Proc. Natl. Acad. Sci. 97, 4426-4429.

Cramer, F.H., 1966. Palynomorphs from the Siluro-Devonian boundary in N. W. Spain. Notas y Comunicaciones del Instituto Geologico y Minero de Espana. 85, pp. 71-82.

Crane, P.R., Herendeen, P., Friis, E.M., 2004. Fossils and plant phylogeny. Am. J. Bot. 91, 1683-1699.

Edwards, D., Feehan, J., 1980. Records of Cooksonia-type sporangia from late Wenlock strata in Ireland. Nature 287, 41-42.

Edwards, D., Wellman, C.H., 2001. Embryophytes on land: the Ordovician to Lochkovian (Lower Devonian) Record. In: Gensel, P.G., Edwards, D. (Eds.), Plants Invade the Land. Columbia University Press, New York, pp. 3-28 (204 pp.).

Edwards, D., Davies, K.L., Axe, L., 1992. A vascular conducting strand in the early land plant Cooksonia. Nature 357, 683-685.

Fanning, U., Richardson, J.B., Edwards, D., 1988. Cryptic evolution in an early land plant. Evol. Trends Plants 2, 13-24.

Glasspool, I.J., Edwards, D., Axe, L., 2004. Charcoal in the Silurian as evidence for the earliest wildfire. Geology 32, 381-383.

Graham, L.E., 1993. Origin of Land Plants. Wiley.

Gray, J., 1985. The microfossil record of early land plants; advances in understanding of early terrestrialization, 1970-1984. Philos. Trans. R. Soc. Lond. B 309, 167-195.

Guo, C.-Q., Edwards, D., Wu, P.-C., Duckett, J.G., Hueber, F.M., Li, C.-S., 2012. Riccardiothallus devonicus gen. et sp. nov., the earliest simple thalloid liverwort from the Lower Devonian of Yunnan, China. Rev. Palaeobot. Palynol. 176-177, 35-40.

Hennelly, J.P.F., 1958. Spores and pollen from a Permian-Triassic transition, N. S. W. Proc. Linnean Soc. NSW 83, 363-369.

Hernick, L.V., Landing, E., Bartowski, K.E., 2008. Earth's oldest liverworts-Metzgeriothallus sharonae sp. nov. from the Middle Devonian (Givetian) of eastern New York, USA Rev. Palaeobot. Palynol. 148, 154-162.

Hints, O., Paris, F., Al-Hajri, S., 2008. Discovery of late Ordovician scolecodonts from the Qusaiba-1 core hole, Arabian Peninsula, and its palaeogeographical implications. Terra Nostra 2008 (2), 117-118.

Hints, O., Paris, F., Al-Hajri, S., 2014. Late Ordovician scolecodonts from the Qusaiba-1 core hole, central Saudi Arabia, and their palaeogeographical affinities. Rev. Palaeobot. Palynol.

Hoffmeister, W.S., 1959. Lower Silurian plant spores from Libya. Micropaleontology 5 , 331-334.

Ishchenko, A.M., 1952. Atlas of Microspores and Pollen of the Middle Carboniferous of the Western Part of the Donets Basin. Izvestiia Akademii Nauk SSR, pp. 1-83, (in Russian).

Johnson, N.G., 1985. Early Silurian palynomorphs from the Tuscarora Formation in central Pennsylvania and their paleobotanical and geological significance. Rev. Palaeobot. Palynol. 45, 307-360.

Kenrick, P., Crane, P.R., 1997. The Origin and Early Diversification of Land Plants: A Cladistic Study. Smithsonian Institution Press, Washington.

Kenrick, P., Wellman, C.H., Schneider, H., Edgecombe, G.D., 2012. A timeline for terrestrialization: consequences for the carbon cycle in the Palaeozoic. Philos. Trans. R. Soc. B 367, 519-536.

Le Hérissé, A., Al-Ruwali, M., Miller, M., Melvin, J., 2008. Late Ordovician organicwalled protists from the QUSAIBA-1 shallow core (NW Saudi Arabia). Terra Nostra 2, 159

Le Hérissé, A., Molyneuz, S., Miller, M.A., 2014. Late Ordovician to early Silurian organicwalled microphytoplankton (acritarchs, prasinophytes) from the Qusaiba-1 shallow core hole, central Saudi Arabia. Rev. Palaeobot. Palynol.

McGregor, D.C., Camfield, M., 1976. Upper Silurian? to Middle Devonian spores of the Moose River Basin, Ontario. Geol. Surv. Can. Bull. 263, 1-63.

Melvin, J., 2014. Lithostratigraphy and depositional history of Upper Ordovician and lowermost Silurian sediments recovered from the Qusaiba-1 shallow corehole, Qasim region, central Saudi Arabia. Rev. Palaeobot. Palynol.

Miller, M.A., Al-Ruwaili, M.H., 2007. Preliminary palynological investigation of Saudi Arabian Upper Ordovician glacial sediments. Rev. Micropaleontol. 50, 17-26.

Miller, M.A., Eames, L.E., 1982. Palynomorphs from the Silurian Medina Group (Lower Llandovery) of the Niagara Gorge, Lewiston, New York, U.S.A. Palynology 6, 221-254.

Miller, M.A., Melvin, J., 2005. Significant new biostratigraphic horizons in the Qusaiba Member of the Silurian Qalibah Formation of central Saudi Arabia, and their sedimentologic expression in a sequence stratigraphic context. GeoArabia 10, 49-92.

Paris, F., Miller, M., Al-Hajri, S., Zalesiewicz, J., Williams, M., 2008a. Aeronian and Telychian chitinozoans from Central Saudi Arabia. Terra Nostra 2, 215.

Paris, F., Verniers, J., Miller, M., Al-Hajri, S., Melvin, J., 2008b. Biostratigraphy of Late Ordovician chitinozoans from Northwest Saudi Arabia. Terra Nostra 2, 216.

Paris, F., Miller, M., Al-Hajri, S., Zalasiewicz, J., 2014a. Early Silurian chitinozoans from the Qusaiba type area, North Central Saudi Arabia. Rev. Palaeobot. Palynol.

Paris, F., Verniers, J., Miller, M., Al-Hajri, S., Melvin, J., Wellman, C.H., 2014b. Late Ordovicianearliest Silurian chitinozoans from the Qusaiba-1 core hole, (North Central Saudi Arabia) and relation to the Hirnantian Glaciation. Rev. Palaeobot. Palynol.

Potonié, R., Kremp, G., 1954. Die Gattungen der paläozoischen Sporae dispersae und ihre Stratigraphie. Geol. Jahrb. 69, 111-194.

Qiu, Y.-L., Li, L., Bin, W., Chen, Z., Knoop, V., Groth-Malonek, M., Dombrovska, O., Lee, J., Kent, L., Rest, J., Estabrook, G.F., Hendry, T.A., Taylor, D.W., Testa, C.M., Ambros, M., Crandall-Stotler, B., Duff, R.J., Stech, M., Frey, W., Quandt, D., Davis, C.C., 2006. The deepest divergences in land plants inferred from phylogenomic evidence. Proc. Natl. Acad. Sci. 103, 15511-15516.
Richardson, J.B., 1988. Late Ordovician and Early Silurian cryptospores and miospores from northeast Libya. In: El-Arnauti, A., Owens, B., Thusu, B. (Eds.), Subsurface Palynostratigraphy of Northeast Libya. Garyounis University Publications, Benghazi, Libya, pp. 89-109.

Richardson, J.B., 1996a. Chapter 18A. Lower and Middle Palaeozoic records of terrestria palynomorphs. In: Jansonius, J., McGregor, D.C. (Eds.), Palynology: Principles and Applications 2. American Association of Stratigraphic Palynologists Foundation, Salt Lake City, pp. 555-574.

Richardson, J.B., 1996b. Taxonomy and classification of some new Early Devonian cryptospores from England. Spec. Pap. Palaeontol. 55, 7-40.

Richardson, J.B., Lister, T.R., 1969. Upper Silurian and Lower Devonian spore assemblages from the Welsh Borderland and South Wales. Palaeontology 12, 201-252.

Richardson, J.B., Streel, M., Hassan, A., Steemans, P., 1982. A new spore assemblage to correlate between the Breconian (British Isles) and Gedinnian (Belgium). Ann. Soc. Geol. Belg. 105, 135-143.

Rubinstein, C.V., Gerrienne, P., de la Puente, G.S., Astini, R.A., Steemans, P., 2010. Early Middle Ordovician evidence for land plants in Argentina (eastern Gondwana). New Phytol. 188, 365-369.

Scotese, C.R., 2013. Paleomap project. Website http://www.scotese.com (accessed 12th February 2013).

Senalp, M., Al-Ruwali, M.H., Miller, M.A., 2002. New evidence on the stratigraphy of the Ordovician-Silurian boundary in Saudi Arabia. GeoArabia 7, 298-299.

Steemans, P., 2000. Miospore evolution from the Ordovician to the Silurian. Rev. Palaeobot. Palynol. 113, 189-196.

Steemans, P., Le Hérissé, A., Bozdogan, N., 1996. Ordovician and Silurian cryptospores and miospores from Southeastern Turkey. Rev. Palaeobot. Palynol. 93, 35-76.

Steemans, P., Higgs, K., Wellman, C.H., 2000. Cryptospores and trilete spores from the Llandovery, NYYM-2 borehole, Saudi Arabia. In: Al-Hajri, S., Owens, B. (Eds.), Stratigraphic palynology of the Palaeozoic of Saudi Arabia. GeoArabia Special Publication 1, pp. 92-115.

Steemans, P., Wellman, C., Miller, M., Al-Ruwali, M., 2008. An Ordovician cryptospore and trilete spore assemblage from Saudi Arabia. Terra Nostra 2, 266.

Steemans, P., Le Hérissé, A., Melvin, J., Miller, M.A., Paris, F., Verniers, J., Wellman, C.H., 2009 Origin and radiation of the earliest vascular land plants. Science 324, 353.

Steemans, P., Wellman, C.H., Gerrienne, P., 2010. Paleogeographic and paleoclimatic considerations based on Ordovician to Lochkovian vegetation. In: Vecoli, M. Clement, M. Meyer-Berthaud, B. (Eds.), The Terrestrialization Process: Modelling Complex Interactions at the Biosphere-Geosphere Interface. Geological Society, London, Special Publications 339, pp. 49-58.

Streel, M., 1964. Une association de spores du Givétien inférieur de la Vesdre, à Goé (Belgique). Ann. Soc. Geol. Belg. 87, 1-30.

Strother, P.K., 1991. A classification schema for the cryptospores. Palynology 15, 219-236.

Strother, P.K., Al-Hajri, S., Traverse, A., 1996. New evidence for land plants from the lower Middle Ordovician of Saudi Arabia. Geology 24, 55-58.

Strother, P.K., 2000. Cryptospores: the origin and early evolution of the terrestrial flora. In: Gastaldo, R.A., DiMichele, W.A. (Eds.), Phanerozoic terrestrial ecosystems. The Paleontological Society, pp. 3-20.

Strother, P.K., Traverse, A., Vecoli, M., 2015. Cryptospores from the Hanadir Shale Member of the Qasim Formation, Ordovician (Darriwilian) of Saudi Arabia: Taxonomy and systematics. Rev. Palaeobot. Palynol. 212, 97-110 (this volume).

Strother, P.K., Traverse, A., 1979. Plant microfossils from the Llandoverian and Wenlockian rocks of Pennsylvania. Palynology 3, 1-21.

Taylor, W.A., 2001. Evolutionary hypothesis of Cryptospore producing plants based on wall ultrastructure In: Goodman, D.K Clarke, RT (Eds.), Proceedings of the IX International palynological Congress Houston, Texas, U.S.A., 1996. American Association of Stratigraphical Palynologists Foundation, Dallas, Texas, pp. 11-15.

Traverse, A., 2007. Paleopalynology, 2nd ed. Springer.

Wellman, C.H., 1996. Cryptospores from the type area of the Caradoc Series in southern Britain. Spec. Pap. Palaeontol. 55, 103-136.

Wellman, C.H., Gray, J., 2000. The microfossil record of early land plants. Philos. Trans. R Soc. Lond. B 355, 717-732.

Wellman, C.H., Richardson, J.B., 1993. Terrestrial plant microfossils from Silurian inliers of the Midland Valley of Scotland. Palaeontology 36, 155-193.

Wellman, C.H., Richardson, J.B., 1996. Sporomorph assemblages from the "Lower Old Red Sandstone" at Lorne, Scotland. Spec. Pap. Palaeontol. 55, 41-101.

Wellman, C.H., Edwards, D., Axe, L., 1998a. Permanent dyads in sporangia and spore masses from the Lower Devonian of the Welsh Borderland. Bot. J. Linn. Soc. 127, 117-147.

Wellman, C.H., Edwards, D., Axe, L., 1998b. Ultrastructure of laevigate hilate spores in sporangia and spore masses from the Upper Silurian and Lower Devonian of the Welsh Borderland. Philos. Trans. R. Soc. Lond. B 353, 1983-2004.

Wellman, C.H., Steemans, P., Higgs, K., 2000. Spore assemblages from a Silurian sequence in borehole HWYH-151 from Saudi Arabia. In: Al-Hajri, S., Owens, B. (Eds.), Stratigraphic Palynology of the Palaeozoic of Saudi Arabia. GeoArabia Special Publication 1, pp. 116-133.

Wellman, C.H., Osterloff, P.L., Mohiuddin, U., 2003. Fragments of the earliest land plants. Nature 425, 282-285.

Wellman, C.H., Kerp, H., Hass, H., 2006. Spores of the Rhynie chert plant Aglaophyton (Rhynia) major (Kidston and Lang) Edwards, 1986. Rev. Palaeobot. Palynol. 142, 229-250.

Wellman, C.H., Steemans, P., Miller, M., 2008. Trilete spores from the Ordovician of Saudi Arabia: earliest evidence for vascular plants and their immediate predecessors ("protracheophytes"). Terra Nostra 2, 304

Zalasiewicz, J.M., Williams, M., Miller, M., Page, A., Blackett, E., 2007. Early Silurian (Llandovery) graptolites from central Saudi Arabia: first documented proof of Telychian faunas from the Arabian Peninsula. GeoArabia 12, 15-36. 